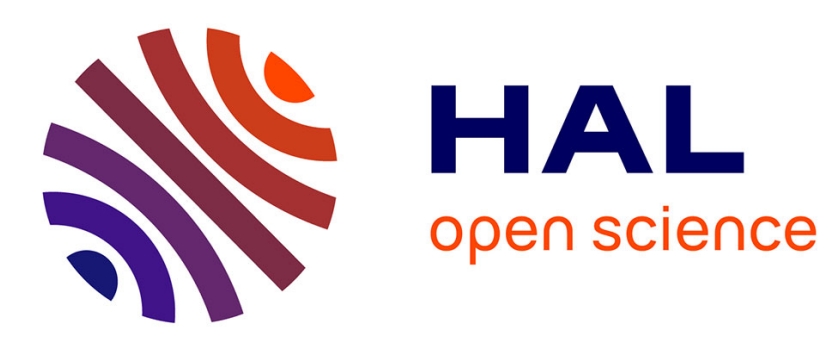

\title{
Mineral fertilizers in the farming systems of sub-Saharan Africa. A review
}

Jonas Chianu, Justina Chianu, Mairura

\section{To cite this version:}

Jonas Chianu, Justina Chianu, Mairura. Mineral fertilizers in the farming systems of sub-Saharan Africa. A review. Agronomy for Sustainable Development, 2012, 32 (2), pp.545-566. 10.1007/s13593011-0050-0 . hal-00930525

\section{HAL Id: hal-00930525 \\ https://hal.science/hal-00930525}

Submitted on 1 Jan 2012

HAL is a multi-disciplinary open access archive for the deposit and dissemination of scientific research documents, whether they are published or not. The documents may come from teaching and research institutions in France or abroad, or from public or private research centers.
L'archive ouverte pluridisciplinaire HAL, est destinée au dépôt et à la diffusion de documents scientifiques de niveau recherche, publiés ou non, émanant des établissements d'enseignement et de recherche français ou étrangers, des laboratoires publics ou privés. 


\title{
Mineral fertilizers in the farming systems of sub-Saharan Africa. A review
}

\author{
Jonas N. Chianu • Justina N. Chianu • \\ Franklin Mairura
}

Accepted: 12 July 2011 /Published online: 7 October 2011

(C) INRA - DIB / Springer-Verlag France 2011

\begin{abstract}
In sub-Saharan Africa (SSA), traditional farming methods have led to severe nutrient depletion, low crop yields, and poverty, leaving many farm families disappointed. The situation is aggravated by low use of fertilizers by farmers, lack of policy and institutional support, weak fertilizer markets, farmers' lack of access to credit and inputs, inappropriate fertilizer packaging sizes, deteriorating soil science capacity, and weak agricultural extension. This leads to a huge gap between the actual and potential crop yields and widespread poverty. Opportunities, options, and innovations are available to turn around this situation and reduce poverty in Africa. We reviewed the status of agricultural soils of sub-Saharan Africa, the factors contributing to their current status, and the existing and emerging opportunities for addressing the soil fertility challenges. The major points are (1) the soils in SSA have continued to be characterized by huge and widespread negative nutrient imbalances and low productivity, and (2) the factors contributing to declining soil fertility in Africa
\end{abstract}

Jonas N. Chianu $(\bowtie)$

Agriculture \& Agro-Industry (OSAN) Department,

African Development Bank,

B.P. 323 - 1002, Tunis Belvedere,

Tunis, Tunisia

e-mail: j.chianu@afdb.org

Jonas N. Chianu

e-mail: jchianu@yahoo.com

Justina N. Chianu

Unit 1, Pacific Residence, David Osieli Road, Westlands,

Nairobi, Kenya

e-mail: justinachianu@yahoo.com

F. Mairura

TSBF-CIAT, c/o World Agroforestry Centre (ICRAF),

UN Avenue, Gigiri, PO Box 30677, Nairobi, Kenya

e-mail: f.mairura@cgiar.org

are not abating. The way forward includes: balanced fertilization; input-output market development; improved crop management, and the use of nutrient budgets to inform policy and ensure that farmers and other land managers enjoy the profitable use of farm inputs including mineral fertilizers and agro-minerals.

Keywords Mineral fertilizers · Farming systems · Challenges $\cdot$ Sub-Saharan Africa

\section{Acronyms and abbreviations}

AATF African Agricultural Technology Foundation

$\mathrm{AE}$

AEZs

AfDB

AFFM

BNF

C

CA

CAN

DAP

FAO

FOB

FSR

IPNM

ISFM

$\mathrm{K}$

KARI

$\mathrm{KCl}$

$\mathrm{Kg}$

MoA

MoA-NAL Ministry of Agriculture National Agricultural

$\mathrm{N}$

NPK

Agronomic efficiency

Agro-ecological zones

African Development Bank

Africa Fertilizer Financing Mechanism

Biological nitrogen fixation

Carbon

Conservation agriculture

Calcium ammonium nitrate

Di-ammonium phosphate

Food and Agriculture Organization of the United Nations

Free on board

Farming Systems Research

Integrated Plant Nutrient Management

Integrated Soil Fertility Management

Potassium

Kenya Agricultural Research Institute

Potassium chloride

Kilogram

Ministry of Agriculture

Laboratories

Nitrogen

Nitrogen phosphorus potassium 


$\begin{array}{ll}\text { OECD } & \begin{array}{l}\text { Organization for Economic Co-operation and } \\ \text { Development }\end{array} \\ \text { P } & \text { Phosphorus } \\ \text { PKS } & \text { Phosphorus potassium sulfur } \\ \text { PPP } & \text { Public-private partnership } \\ \text { PR } & \text { Phosphate rock } \\ \text { SCODP } & \text { Sustainable Community Oriented } \\ & \text { Development Programme } \\ \text { SSA } & \text { Sub-Saharan Africa } \\ \text { SSP } & \text { Single superphosphate } \\ \text { T\&V } & \text { Training and visit } \\ \text { TSP } & \text { Triple superphosphate }\end{array}$

Contents

1. Introduction. . . . . . . . . . . . . . . . 2

2. Soil fertility challenges. . . . . . . . . . . .

3. Addressing soil fertility challenges in Africa. . . . . .8

4. Fertilizers and plant growth. . . . . . . . . 10

5. Fertilizer production and importation. .........11

6. Factors constraining farmers' fertilizer use. . . . . . . 13

7. Profitability of fertilizer use in Africa. ..........14

8. Efficiency in the use of fertilizers. ............15

9. Synergy between inorganic and organic fertilizers. . . . 16

10. Paradigm shifts on fertilizers. . . . . . . . . . 17

11. Balanced fertilization. . . . . . . . . . . . . 17

12. Conclusion. . . . . . . . . . . . . . . . 18

13. References. ..................... 18

\section{Introduction}

Soils have played pivotal roles over the ages. African agricultural soils have traditionally played a significant role in the socio-economic development of the continent. The capacity to produce plant biomass remains an essential productivity function of the soil. This function is closely associated with food security, energy, water supply, carbon balance, and climate change (Mueller et al. 2010). It can only be delivered by a fertile and/or a healthy soil. A soil is said to be fertile if it has the capacity to retain, cycle, and supply the essential nutrients for plant growth over many years. A healthy soil is one that is capable of supporting ecosystem services on a sustained basis (Millennium Ecosystem Assessment 2005). Soil fertility ensures robust plant growth and good crop yields and relates to: (1) the nutrient status of the soil, (2) the activities of soil organisms, (3) the amounts and types of clay minerals, (4) air exchanges, and (5) biological, chemical, or physical processes (Alley and Vanlauwe 2009).
Unfortunately, however, the role of the soil is fast waning in Africa. This is because of the severe nutrient depletion and the widespread decline in the fertility of African soils, leading to abysmally low crop yields (see Table 1). The decline in soil fertility is the leading cause of the declining per capita food production in SSA (Sanchez et al. 1997). Industrial development is nearly impossible without agricultural intensification (Eicher 1999). In many cases, farmers' yields for cereals rarely exceed 0.5 tha $^{-1}$ while a potential of 6-8 tha ${ }^{-1}$ is attained in research station trials and on commercial farms (Bationo et al. 2006). Fertilizers sustainably increase crop productivity by 50 $100 \%$. In Uganda, maize yields at research stations have been found to be at least eight times higher than what a typical farmer harvests, with other crops showing similar large yield gaps (Bayite-Kasule 2009).

The situation is aggravated by factors such as the dismally low use of fertilizers by smallholder farmers, insufficient knowledge in the use of fertilizers among farmers, lack of policy and institutional support, weak fertilizer markets, termination of farm input subsidies as required under the structural adjustment program, farmers' lack of access to credit and farm inputs, low quality of available fertilizers, inappropriate fertilizer packaging sizes, low farmer literacy and poverty, deteriorating soil science capacity, weak agricultural extension, and climate change. As a result, a huge gap now exists between the actual crop yields obtained by farmers and the potential yield possible of all crops. These are the direct results of huge negative soil nutrient balance, culminating in widespread poverty in Africa (Stoorvogel et al. 1993; Breman et al. 2005).

The gloomy situation notwithstanding, Africa can capitalize on available opportunities to turn things around and reduce poverty among its citizens. Africa accounts for about $75 \%$ of the deposits of agro-minerals in the world. This has, however, remained largely untapped. Instead, most of the African countries have continued to import fertilizers. There have also been some recent initiatives and innovations that provide options for reversing the vicious situation above. These include farmer adoption of proven technologies such as integrated soil fertility management, input use efficient improved germplasm, and increased application of agrominerals and $\mathrm{N}$ fertilizers. Available innovations also exist in the areas of input-output market development, biological nitrogen fixation, use of nutrient budgets for efficiency and to inform nutrient management policy, reintroduction of fertilizer subsidy, regulated repackaging of fertilizers into affordable sizes, and soil testing for efficient fertilizer recommendations. However, these innovations need policy and institutional support to yield the required effects. 
Table 1 Fertilizer consumption and current yields/realistic targets for maize, millet, and cassava in five sub-regions of Africa (after FAO 2005)

\begin{tabular}{|c|c|c|c|c|c|c|c|}
\hline \multirow[t]{2}{*}{ African Sub-region } & \multirow{2}{*}{$\begin{array}{l}\text { Fertilizer consumption } \\
\mathrm{kg} \mathrm{ha}^{-1}\end{array}$} & \multicolumn{2}{|c|}{ Maize yield } & \multicolumn{2}{|c|}{ Millet yield } & \multicolumn{2}{|c|}{ Cassava yield } \\
\hline & & Current & Target & Current & Target & Current & Target \\
\hline Central & 0.9 & 798 & 2,455 & 673 & 1,709 & 8,032 & 12,175 \\
\hline East & 15.3 & 1,631 & 2,945 & 1,287 & 2,108 & 12,256 & 15,540 \\
\hline Sahel & 5.5 & 1,516 & 3,065 & 665 & 1,633 & 7,523 & 11,395 \\
\hline Southern & 16.7 & 1,168 & 2,447 & 617 & 1,416 & 7,347 & 10,544 \\
\hline West & 5.9 & 1,143 & 2,683 & 987 & 1,950 & 10,406 & 14,255 \\
\hline
\end{tabular}

Potential yields are based on on-farm Integrated Soil Fertility Management (ISFM) approaches (Sanginga and Woomer 2009)

The objective of this review paper is to highlight the status of agricultural soils of sub-Saharan Africa, the factors contributing to their current status, chart the opportunities for addressing the soil fertility challenges and how to ensure that African soils continue to play significant roles in the socio-economic development of the continent (Figs. 1 and 2).

\section{Soil fertility challenges}

Soil fertility challenges in SSA can be very serious. Severe soil degradation can lead to such strong constraints that even legumes perform poorly and are unable to produce sufficient biomass. Large regions in Africa are characterized by strongly acid soils coupled with aluminum toxicity. Africa exhibits the lowest rate of fertilizer use in the world, with an average consumption estimated at $8.3 \mathrm{~kg} \mathrm{ha}^{-1}$ (Morris et al. 2007; Sanginga and Woomer 2009). In 2002, approximately 1.38 million tons of fertilizers were applied. This represents $2 \%$ of the worldwide fertilizer demand estimated at 64.5 million tons. A recent study in Uganda showed that only $1 \%$ of the total farm households surveyed applied inorganic fertilizers to their crops (Bayite-Kasule 2009). Based on 2004 data from 38 African countries, the

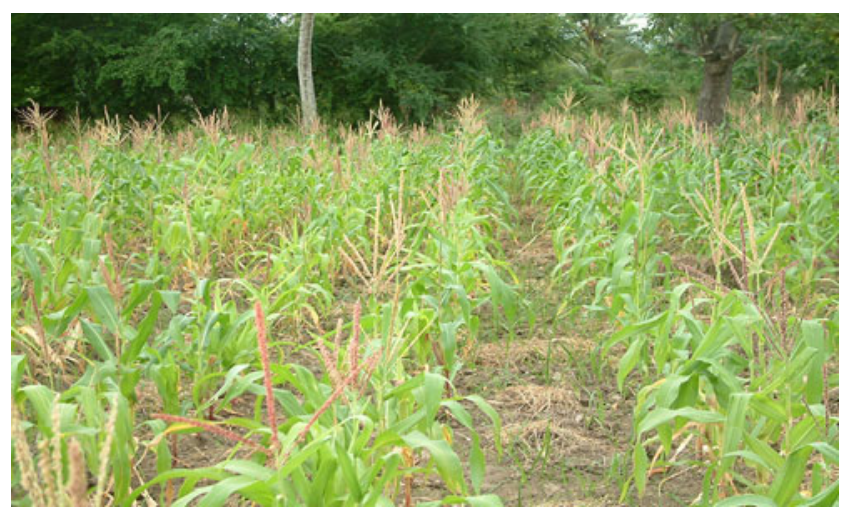

Fig. 1 Effect of soil fertility depletion on productivity, Kenya average fertilizer consumption ranges from $0.3 \mathrm{~kg} \mathrm{ha}^{-1}$ (for Central African Republic) to $42.5 \mathrm{~kg} \mathrm{ha}^{-1}$ (Zimbabwe; FAOSTAT 2004). Fertilizer consumption of $<5 \mathrm{~kg} \mathrm{ha}^{-1}$ occurs in $55 \%$ of these 38 countries. Given that some are coastal countries, factors other than problems of inland transportation must have been responsible for the observed low levels of fertilizer use (Morris et al. 2007; Fig. 3).

The factors that contribute to soil fertility challenges include the removal of input subsidy, high cost of moving fertilizers from ports to the farm, untimely availability and low quality of fertilizers, poor cultural practices, inadequate supplies of organic and inorganic fertilizers, deteriorating soil science capacity and weak agricultural extension services, lack of soil fertility maintenance plans, nutrient mining and low nutrient use efficiency, inappropriate fertilizer recommendations, differences in crop response to fertilizers, and nutrient deficiency and climate change. These are further discussed below.

An important component of the development strategies of newly independent African nations during the 1960s and 1970s was the establishment of agricultural cooperatives (Lynam and Blackie 1994). Directed through parastatal boards that were subject to political influences, the cooperatives were designed to promote the export of commodities. There was distrust, because these coopera-

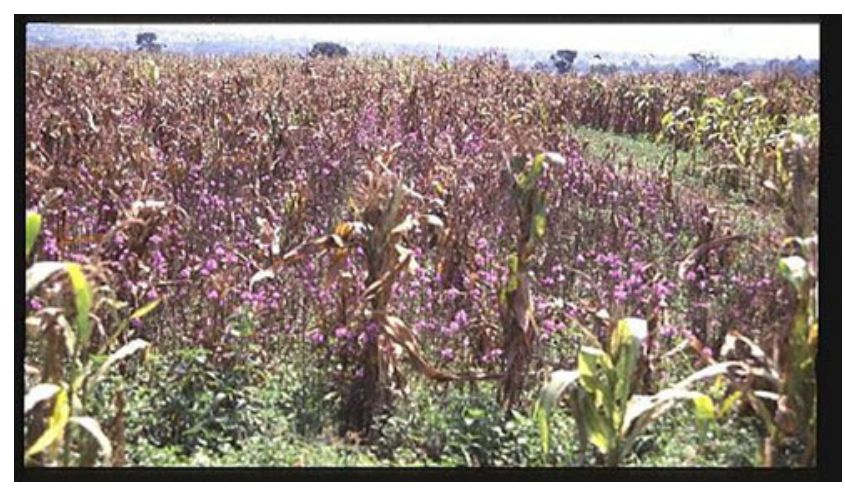

Fig. 2 Striga weed infestation due to soil fertility depletion, Kenya 

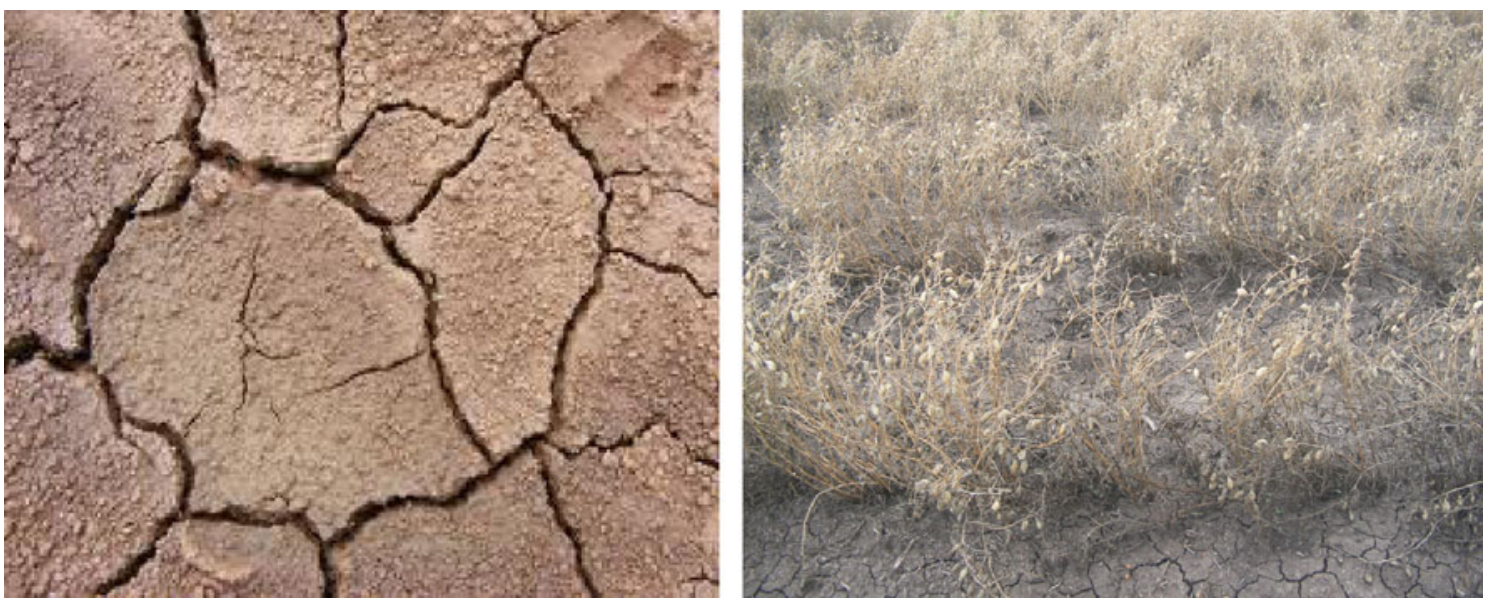

Fig. 3 Highly degraded soil

tives did little to promote the welfare of the farmers (Eicher 1999). Under the structural adjustment of the 1980s and 1990s, these monopolistic cooperatives were either disbanded or privatized, affecting their input subsidy programs (IFDC 2003; Smaling et al. 2006). Following this disbandment, there were too few private investors to fill the vacuum in input supply (Jayne et al. 2002; Omamo and Farrington 2004). With the ensuing poor prices for farm produce and poor agricultural infrastructure, smallholder farmers felt abandoned.

The fertilizer shortage is mainly attributable to high transaction costs and inefficiencies throughout the fertilizer production-consumption chain (Quinones et al. 1997). When the rather high price of mineral fertilizers at the farm gate is partitioned and attributed, the FOB price accounts only for $40-60 \%$. Another key item is the cost of trucking from the sea port to the in-country warehouse, which accounts for $15-34 \%$, explaining the usually high farm gate prices of mineral fertilizers in Africa. Sea shipping accounts for only $10-12 \%$ of the farm gate price. Combining simulation techniques with regional farm enterprise analysis, Chianu et al. (2008) showed that structural changes in fertilizer procurement which reduced the farm gate price by $15 \%$ led to $6 \%$ additional income under low own price elasticity $(-0.38), 22 \%$ under medium own price elasticity $(-1.43)$, and $34 \%$ under high own price elasticity $(-2.24)$. Switching from one scenario to another indicated the potential for further increases of $20-32 \%$ in farm incomes. The authors recommended increased support for structural interventions that reduce the farm gate price of fertilizers and other farm inputs.

Untimely availability and low quality also constitute a major constraint to fertilizer use. Throughout Africa, sufficient quantities of mineral fertilizers are not available at the right times during the year. Besides, fertilizers composed of the major limiting nutrients for specific areas and local knowledge on how best to apply these is often lacking. The use of the correct types of fertilizer is of paramount importance for their efficient utilization. Nutrients supplied through mineral fertilizers must match crop requirements. Unfortunately, the little amount of fertilizer available in SSA is often not the type required by various crops. Sometimes, fertilizers fail to meet the expected quality needs because manufacturers and distributors commonly lack the essential agronomic information to formulate the appropriate nutrient compositions for their products (Sanginga and Woomer 2009). For instance, sulfur (S) is often the third limiting nutrient in soils after $\mathrm{N}$ and phosphorus (P). Yet it is seldom included in the fertilizers commonly available. The widely available calcium-ammonium-nitrate, di-ammonium phosphate, Triple Super phosphate, and urea do not contain S. Therefore, an important use must be made of the sulfur-bearing agro-minerals, such as elemental sulfur, pyrite, or iron sulfide, and gypsum or calcium sulfate, in the supplementation of imported mineral fertilizers that lack sulfur. Crop nutrient needs depend on the environment and change with time and intensification (Bayite-Kasule 2009). Added to these considerations is the fact that adulteration is common in several African countries, and discourages farmers from investing in fertilizers.

The ways the soil resources are managed contribute to the depletion of soil nutrients (Breman et al. 2005). Examples include continuous cultivation, mono-cropping of cereals, and intensive tillage. These lead to nutrient depletion, severe land and soil resource degradation, and the food insecurity that is widespread in Africa (Smaling et al. 1997; Hartemink 2003). As cropping frequency increases, shorter fallow intervals result in the incomplete re-accumulation of nutrients (Hauser et al. 2006). In areas with better access to farm inputs and good agricultural commodity markets, farmers have abandoned the fallow 
system and are now confronted with severe physical soil degradation and nutrient depletion because market-led agriculture has not kept pace with the deteriorating soil resource base (Sanginga and Woomer 2009). Long-term intensive soil tillage leads to the deterioration of the soils' physical and biological properties and to productivity loss (Derpsch 2008). The challenge is to establish fertility management practices that sustain land productivity in the absence of fallows (Van Reuler and Janssen 1996). Monocropping must be broken, probably through the introduction of integrated soil fertility management packages consisting of legumes and fertilizers in rotation with cereals, with rhizobial inoculants probably accompanying legume seeds (Van Rensburg et al. 1976; Woomer et al. 1999).

Inadequacies in the supplies of organic and inorganic nutrients have created fertility gradients within farms. Across distances of $50-100 \mathrm{~m}$, a large range in soil C contents has been observed due to a preferential allocation of organic residues and fertilizers and to differences in livestock ownership and other resource endowments (Shepherd and Soule 1998; Tittonell et al. 2005b; Zingore et al. 2007a). In addition, poverty prevents small-scale farmers from taking advantage of soil analysis. The cost of soil preparation and $\mathrm{N}-\mathrm{P}-\mathrm{K}$ analysis is about US $\$ 12.65$ on average, sufficient funds for the purchase of about $20 \mathrm{~kg}$ of mineral fertilizer. Farming households affected by HIV/AIDS and chronic illness are forced to divert incomes to medication instead of to farm improvements (Baylies 2002; Wiggens and Slater 2005).

Soil science capacities have been deteriorating in African institutions, leading to a limited access to soil testing services and the inability to understand characteristics such as chemical properties, soil texture, and soil bulk-density which influence crop root development and nutrient uptake (Alley and Vanlauwe 2009). Conventional assessments of soil are expensive with problems of quality control and there are few reliable and inexpensive soil test kits (Okalebo et al. 2002). Related to this problem is low level of literacy among smallholder farmers in SSA that constrains the dissemination of information on soil fertility. For instance, the literacy rate among farmers is $16 \%$ in Niger compared with an average of $97 \%$ in Europe. In addition, agricultural extension remains poorly funded, weak, and inadequate compared with the huge number of farming clients (Lynam and Blackie 1994; Swift and Shepherd 2007). There is also the inconsistency in data and information on fertilizer use for different regions and countries in SSA, especially at finer scales where individual farms may be distinguished. For instance, while Shepherd and Soule (1998) concluded that fertilizer use in Western Kenya was limited to households with the most favorable resource endowments, Crowley and Carter (2000) reported that more than $90 \%$ of farmers in two villages in Western
Kenya used mineral fertilizers. However, up to $81 \%$ of the fields received less than half of the recommended $120 \mathrm{~kg} \mathrm{~N}$ ha $^{-1}$ because of high costs. Similarly, Seward and Okello (1999) and Conway and Toenniessen (2003) noted that, through the intensive fertilizer marketing efforts of the Sustainable Community-Oriented Development Program (SCODP), many farmers in Western Kenya were influenced into using mineral fertilizers. These corroborate a recent finding that improved soil management practices are being steadily adopted within Western Kenya, albeit at a low rate (Sanginga and Woomer 2009). However, the findings contradict the assertion of Tripp (2006) that no evidence supports the adoption of low external inputs technologies by Kenya's poorest farmers and the general belief that mineral fertilizers are not widely applied to food crops by smallholders in African agriculture. Similarly, in the Sahel region of Niger and Burkina Faso, Bationo and Mokwunye (1987) noted that fertilizer is too seldom applied to traditional food crops, such as millet and sorghum.

National soil fertility maintenance strategies exist in only few countries in sub-Saharan Africa, even though average fertilizer application is $8 \mathrm{~kg} \mathrm{ha}^{-1}$. A vast majority of smallholders also have little or no experience with fertilizers and may, therefore, not benefit from their crop productivity-raising effect. Unlike smallholder farmers, commercial farmers invest in nutrient supply to overcome constraints to production to achieve profitable agricultural production enterprises (Okigbo 1990). Also important is the heterogeneity between households within a community, resulting in differing production objectives and resource endowments (Tittonell et al. 2005a; Giller et al. 2006). Ojiem et al. (2006) derived the concept of the "socioecological niche" for targeting integrated soil fertility technologies, adjusting as necessary based on individual farms.

In SSA, outputs are greater than inputs for all nutrients, and this constitutes a constraint to crop production (Stoorvogel et al. 1993). The other constraints include low nutrient use efficiency, salinity in rice production systems, a rapid decline in $\mathrm{N}$ once cropping has commenced, the inability of African soils to supply the quantities of $\mathrm{N}$ required by crops, precipitation in excess of evapotranspiration leading to leaching and a reduction in soil nutrient reserves, low and fast depleting levels of organic matter in agricultural lands in Africa, low levels of soil organic carbon, and insufficient access of crops to $\mathrm{P}$ and micronutrients such as zinc $(\mathrm{Zn})$, iron $(\mathrm{Fe})$, and $\mathrm{S}$ (Woomer et al. 1994; De Vries and Toenniessen 2001; Sanginga et al. 2001; Sanginga and Woomer 2009). In SSA, an average of $22-26 \mathrm{~kg} \mathrm{~N}$ is lost per hectare per year, mainly through harvested products and erosion. Deficits in potassium $(\mathrm{K})$ for developing countries are so substantial that a doubling of the world's production of potash fertilizers would be 
required to balance inputs and off-take and so meet African demand. However, the price of the raw materials of potash fertilizer increased by a factor of 4 during the period from 2007 to 2009 , approaching US $\$ 1,000 \mathrm{t}^{-1}$ in some markets. An annual investment of approximately US \$ 5600 million is needed to replenish soil stocks of K in SSA (Manning 2009). Atmospheric deposition is low. Organic resources that could be an important source of $\mathrm{K}$ are also used for purposes such as construction and fuel. Manufactured fertilizers are either not available or unaffordable (Alley and Vanlauwe 2009). Table 2 gives average nutrient balances for selected countries in SSA and a good idea of the context of the problem. Nutrient balances tended to be worse in 2000 because of increased intensity in cropping, greater erosion, and the lack of inputs from organic or manufactured sources of nutrients.

A detailed evaluation of nutrient inputs, flows, and losses in southern Cameroon concluded that nutrient losses from smallholder operations were $-70 \mathrm{~kg} \mathrm{~N},-3.1 \mathrm{~kg} \mathrm{P}$, and $-21 \mathrm{~kg} \mathrm{~K} \mathrm{ha}^{-1}$ year $^{-1}$. Nutrient balances in the banana production system in Uganda are negative, as up to $82 \%$ of nutrients in the bunch are exported to urban markets (Sanginga and Woomer 2009). Nutrient mining is a reality in SSA (Stoorvogel et al. 1993). Cash crops tend to be much less depleting than food and fodder crops because they receive more fertilizer and manure and many of them are deep rooting, and so better protected the soil against fertility loss. Cash crops have more favorable nutrient balances than district averages in Ghana, Mali, and Kenya (FAO 2004; Table 3).

Table 3 illustrates how the insufficient use of fertilizer is leading to a greater negative effect on the environment, contributing to different forms of land degradation, affect-
Table 3 District- and field-level nutrient balances for selected areas and cash crops in Africa (FAO 2004)

\begin{tabular}{lrrr}
\hline Location and crop & $\mathrm{N}$ & $\mathrm{P}$ & $\mathrm{K}$ \\
& $\mathrm{kg} \mathrm{ha}^{-1}$ year $^{-1}$ & \\
\hline Ghana, Nkawie district & -18 & -2 & -20 \\
Cocoa fields & -3 & 0 & -9 \\
Ghana, Wassa Amenfi district & -4 & -1 & -11 \\
Cocoa fields & -2 & 0 & -9 \\
Kenya, Embu district & -96 & -15 & -33 \\
Coffee fields & -39 & -8 & -7 \\
Tea fields & -16 & -1 & -2 \\
Mali, Koutiala region & -12 & 1 & -7 \\
Cotton fields & -14 & 12 & 17 \\
\hline
\end{tabular}

ing biodiversity and carbon sequestration (Jindal 2006). Soil fertility degradation can be a major contributor to desertification. As a contrast to Table 2, partial nutrient budgets for North America have positive $\mathrm{N}$ balances in all regions, including maize-producing States. Budgets for $\mathrm{P}$ and $\mathrm{K}$ for the six leading maize States were slightly negative, from the export of nutrients in maize and soybean crops (Alley and Vanlauwe 2009). In the absence of inputs, organic matter levels drop to below $50 \%$ of the original values within a few years, depleting at a rate of approximately $4 \%$ per year and resulting in dangerously low organic carbon levels after 15-20 years of cultivation. Below $0.5 \%$ carbon, the situation in many places in Africa, the soil supplies $<50 \mathrm{~kg} \mathrm{~N} \mathrm{ha}^{-1}$ year ${ }^{-1}$, sufficient only for about 1 tha $^{-1}$ per season of maize grain at normal $\mathrm{N}$ use efficiency (Carsky and Iwuafor 1995).
Table 2 Average nutrient balances for selected countries in sub-Saharan Africa (SSA). Source: Alley and Vanlauwe 2009, p. 48; adapted from Roy et al. (2003). With kind permission of IFA

\begin{tabular}{|c|c|c|c|c|c|c|}
\hline \multirow[t]{2}{*}{ Country } & \multicolumn{2}{|l|}{$\mathrm{N}$} & \multicolumn{2}{|l|}{$\mathrm{P}$} & \multicolumn{2}{|l|}{$\mathrm{K}$} \\
\hline & $\begin{array}{l}\text { 1982-1984 } \\
\mathrm{kg} \mathrm{ha}^{-1} \text { year }^{-1}\end{array}$ & 2000 & 1982-1984 & 2000 & 1982-1984 & 2000 \\
\hline Bénin & -14 & -16 & -1 & -2 & -9 & -11 \\
\hline Botswana & 0 & -2 & 1 & 0 & 0 & -2 \\
\hline Cameroon & -20 & -21 & -2 & -2 & -12 & -13 \\
\hline Ethiopia & -41 & -47 & -6 & -7 & -26 & -32 \\
\hline Ghana & -30 & -35 & -3 & -4 & -17 & -20 \\
\hline Kenya & -42 & -46 & -3 & -1 & -29 & -36 \\
\hline Malawi & -68 & -67 & -10 & -10 & -44 & -48 \\
\hline Mali & -8 & -11 & -1 & -2 & -7 & -10 \\
\hline Nigeria & -34 & -37 & -4 & -4 & -24 & -31 \\
\hline Rwanda & -54 & -60 & -9 & -11 & -47 & -61 \\
\hline Senegal & -12 & -16 & -2 & -2 & -10 & -14 \\
\hline Tanzania & -27 & -32 & -4 & -5 & -18 & -21 \\
\hline Zimbabwe & -31 & -27 & -2 & 2 & -22 & -26 \\
\hline
\end{tabular}


Within Sudano-Sahelian agriculture, $\mathrm{P}$ is frequently the nutrient most limiting crop production (Bationo 2008) but is indispensable for tuber production. A large response to $\mathrm{P}$ was seen in highly weathered Ferralsols, where application at a rate of $65 \mathrm{~kg} \mathrm{P} \mathrm{ha}^{-1}$ increased tuber yield from about 3-9 t $\mathrm{ha}^{-1}$ (Malavolta et al. 1965; Howeler et al. 1976). Deficiency of $\mathrm{P}$ can reduce the growth of cassava without recognizable symptoms (Kang 1983). Although the recommended levels of addition to deficient soils range between 15 and $30 \mathrm{~kg} \mathrm{P} \mathrm{ha}^{-1}$, application levels as low as $4 \mathrm{~kg} \mathrm{P} \mathrm{ha}^{-1}$ have resulted in a significant crop response (Jones and Wild 1975). Soil test values of 2 or $3 \mathrm{mg}$ extractable $\mathrm{P} \mathrm{kg}^{-1}$ of soil are not uncommon and increasing the content of $\mathrm{P}$ to $5 \mathrm{mg} \mathrm{kg}^{-1}$ can increase cereal yields by $50-180 \%$ (Bationo 2008). Similarly, although required by plants in small quantities, micronutrients limit plant growth and reduce crop yields when deficient. Increased demand for secondary nutrients and micronutrients may lead to the expression of new deficiencies when their supply becomes limiting (Levin et al. 1993; Bouis et al. 1999; Slingerland et al. 2006). Studies across SSA indicate that many soils become deficient in $\mathrm{Zn}, \mathrm{Fe}$, and $\mathrm{S}$ once macronutrient status is corrected (Sillanpa 1990). More than half the school-age children suffer from iron deficiency or anemia, especially given that most do not have access to means of iron supplementation (Sifri et al. 2003).

Soil nutrient mining remains an option for farmers as long as they do not see any responses in crop yield when fertilizers are applied (Alley and Vanlauwe 2009). Obviously, sustained removal of nutrients means that nutrients will have to be replaced after some time. The speed with which nutrients are depleted depends on the crop yields and the amounts removed in relation to the soil's stocks. In cases of nutrient-rich soils, nutrient balances cannot be used to indicate sustainability or to indicate fertilizer requirements without consideration of the nutrient stocks in the soil (Vanlauwe and Giller 2006). If a study of the nutrient balance indicates a deficit, simply supplying that amount of nutrients in the form of manufactured fertilizers is not sufficient to lead to a balanced nutrient budget since significant portions of the nutrients in added fertilizer, particularly of $\mathrm{N}$, are subject to losses (Woomer and Muchena 1996; Alley and Vanlauwe 2009). National average maize yields remain low (900-1,800 $\mathrm{kg} \mathrm{ha}^{-1}$ ) mainly because of low fertilizer consumption (Table 4).

In cassava-based systems, there is virtually no fertilizer use and nutrients removed as harvest are seldom replenished. Harvested cassava roots remove about $55 \mathrm{~kg} \mathrm{~N}$, $13 \mathrm{~kg} \mathrm{P}$, and $112 \mathrm{~kg} \mathrm{~K} \mathrm{ha}^{-1}$ (Howeler 1991). Even where improved varieties are grown, potential yields of 20-35 t $\mathrm{ha}^{-1}$ are seldom achieved (Fermont et al. 2006). Local varieties yield up to 20 tha $^{-1}$ less than the varieties resistant to Cassava Mosaic Disease. A combination of factors including striga and other pests, diseases, and the non-use of fertilizers contribute to yield losses of over $50 \%$ (Bananuka and Rubaihayo 1994; Bwamiki et al. 1998; Hillocks 2001; Sanginga and Woomer 2009). Striga causes much of its damage before emerging aboveground and inflicts annual maize grain losses of 1.6 million $t$ valued at US \$ 383 million (Odhiambo and Woomer 2005; AATF 2006). Severe agro-climatic and edaphic constraints and the inability of small-scale farmers to have access to the inputs to overcome them limit the gains from higher yielding crop varieties resistant to pests and diseases (Sayang et al. 2002).

Fertilizer recommendations have had little impact on smallholders' production. The earliest fertilizer recommendations in Kenya were based upon independent trials carried out before 1985 (KARI 1994). From 1986, KARI conducted fertilizer response trials at well-characterized sites to generate appropriate district-level recommendations (MoA-NAL 1998; KARI 1994). Experience from KARI's fertilizer use recommendation project (KARI-FURP) shows that in too many cases the recommended fertilizer rates were well beyond the investment capacity of most small farmers. The Western Regional Alliance for Technology Evaluation (WeRate) advanced a low recommended rate for poorer farmers combating striga in West Kenya (AATF 2006). Farmers in different geographical areas of Malawi receive area-specific recommendations for fertility management. When captured into starter packs distributed to farming households in Malawi, this resulted in bumper harvests, raised farmers' knowledge of mineral fertilizers, and increased fertilizer consumption to $39 \mathrm{~kg} \mathrm{ha}^{-1}$, with attention to tobacco (Blackie and Mann 2005; Denning et al. 2009). Related to this is the general bias in fertilizer use in favor of cash crops, large farms, and the rich. In addition, households that are not selling farm produce find it difficult to afford fertilizers (Hartemink 2003). In Mali, although income from cotton made investments possible, extreme soil degradation on other parts of the farm was reported because little fertilizer or manure was applied to the adjacent food crops (Van der Pol 1992). In Africa, fertilizer recommendations have been most effective for cash crops, such as tea, coffee, and sugar grown for well-organized markets, and for hybrid maize, which responds well to fertilizers (Sanginga and Woomer 2009).

A multi-locational use recommendation project in Kenya revealed large locational differences in crop responses to applied fertilizer. In Nitisols (P-fixing), maize responded only to P. In Vertisols (fertile and not P-fixing), maize responded only to the application of $\mathrm{N}$. However, in Arenosols (sandy, poor in nutrients), both $\mathrm{N}$ and $\mathrm{P}$ were essential to maize. However, the patterns of fertilizer use in Kenya vary considerably across conditions, communities, 
Table 4 Fertilizer consumption and maize production in selected countries (adapted from Sanginga and Woomer 2009)

\begin{tabular}{|c|c|c|c|c|}
\hline \multirow[t]{2}{*}{ Region Country } & \multicolumn{2}{|c|}{ Fertilizer consumption } & \multicolumn{2}{|l|}{ Maize production } \\
\hline & Average $\left(\mathrm{kg} \mathrm{ha}^{-1}\right)$ & Total (MT) & Area (x 1000 ha) & Yield $\left(\mathrm{kg} \mathrm{ha}^{-1}\right)$ \\
\hline \multicolumn{5}{|l|}{ East Africa } \\
\hline Ethiopia & 13 & 145,475 & 1,712 & 1,744 \\
\hline Kenya & 29 & 146,151 & 1,547 & 1,564 \\
\hline Uganda & 1 & 7,248 & 652 & 1,781 \\
\hline \multicolumn{5}{|l|}{ Southern Africa } \\
\hline Malawi & 39 & 90,094 & 1,457 & 1,296 \\
\hline Mozambique & 5 & 21,367 & 1,183 & 898 \\
\hline Zambia & 8 & 44,329 & 476 & 1,454 \\
\hline Zimbabwe & 43 & 142,500 & 1,319 & 1,022 \\
\hline \multicolumn{5}{|l|}{ West Africa } \\
\hline Ghana & 4 & 24,648 & 783 & 1,421 \\
\hline Nigeria & 6 & 191,567 & 4,177 & 1,090 \\
\hline Burkina Faso & 3 & 12,422 & 317 & 1,768 \\
\hline
\end{tabular}

and households and are stimulated by profitable agriculture (Smaling et al. 1992; Place et al. 2003).

The under-application of even a single essential plant nutrient also constitutes a cause for environmental concern in agro-ecosystems. Nutrient deficiencies limit the production of biomass and organic matter, leaving the soil exposed to erosion. Decreased soil organic matter reduces water infiltration and retention and yield potential. In Africa, climate change threatens to accelerate desertification which is already proceeding at an alarming rate. Loss of organic carbon with the erosion of topsoil may result in additional emissions of carbon dioxide (Alley and Vanlauwe 2009; AfDB 2009). In Eastern and Central Africa, climate change is projected to affect major economic commodities. There is a need for alternative crop varieties, crop substitution, changes in livestock feeding methods, and sound soil management practices to adapt to these changes (van de Steeg et al. 2009; Fig. 4).
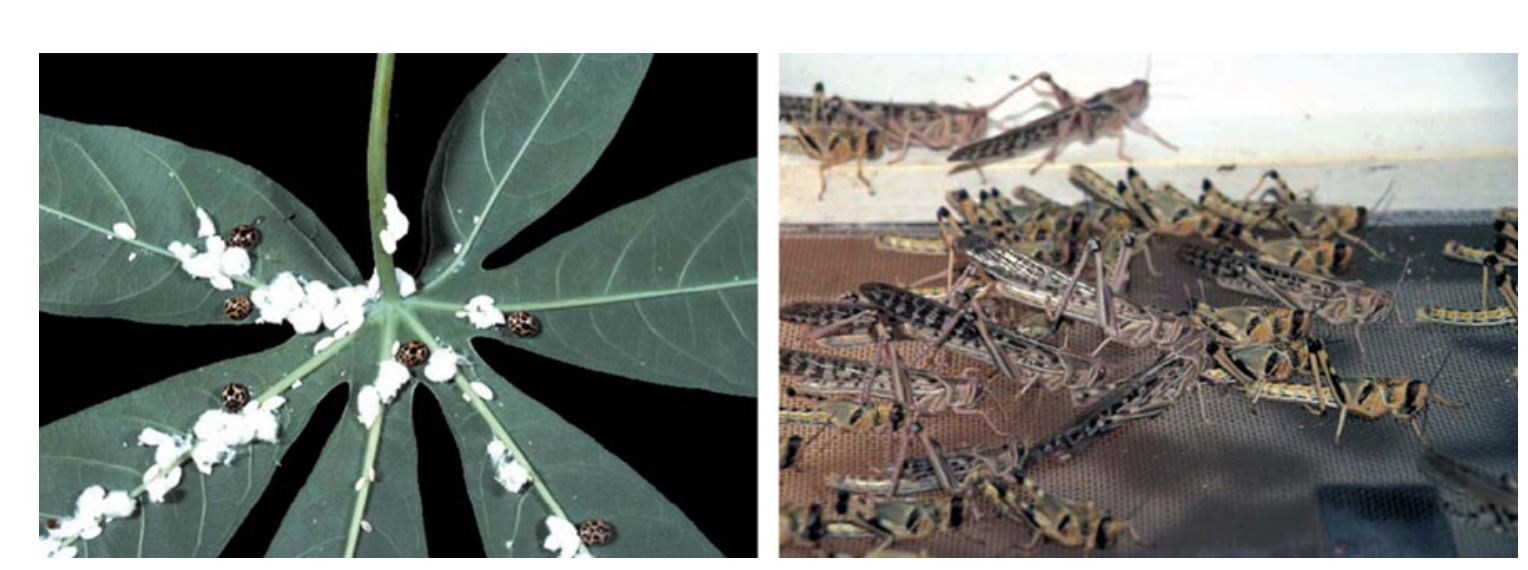

\section{Addressing soil fertility challenges in Africa}

The soil fertility challenges in Section 2 confront farmers in Africa. Knowledge is available on how to respond to the challenges and reduce their effects such as food shortages (Kanyanjua et al. 2000; Gachene and Kimaru 2003). Appropriate responses through the use of agro-minerals, improved technologies and policy, nutrient budgets, integrated plant nutrient management, biological nitrogen fixation, re-introduction of fertilizer subsidies, and soil testing are discussed below.

Agro-minerals, such as limestone, dolomite, and gypsum, have been described as central to large-scale strategies to replenish soil nutrients in Africa (Buresh et al. 1997). However, an increased use of agro-minerals by African farmers would require industrial expansion. Also, land managers must be prepared to invest in external inputs (Woomer et al. 1997; Uphoff et al. 2006). Farmers would need access to the right crop varieties. The strategic 
application of $\mathrm{N}$ fertilizers, including top-dressings, helps to synchronize $\mathrm{N}$ availability and the crop demand. This underscores the growing importance of input-output market development which many development organizations intervening in Africa now recognize as critical for technical advances to be made in soil fertility. Improved supply of farm inputs and reliable produce markets help to create the well-functioning marketing services that stimulate production through better crop and soil management (Lerman 2001).

Promising technologies exist that can significantly contribute to addressing the soil fertility challenges in Africa. Examples include the imazapyr seed coating of herbicide-resistant maize seeds, and intercropping or rotation of cereals with field legumes for the control of striga (Kanampiu et al. 2002; Khan et al. 2005). Pilot testing in Western Kenya resulted in a yield improvement of $785 \mathrm{~kg}$ grain $\mathrm{ha}^{-1}$, a reduction of $84 \%$ in striga expression, and widespread acceptance by farmers (Woomer et al. 2008). The reduction of striga through crop management is an important determinant of soil health (Otieno et al. 2005; Sanginga and Woomer 2009). Policies that ensure the longterm adoption of the best soil fertility management practices by smallholder farmers could counteract the negative nutrient balance common in SSA (Smaling et al. 1997).

A plant nutrient budget provides a rational basis for the development of a country-wide program of education on soil fertility to address imbalances through policy enactment (Jiyun et al. 1999). It has been used to quantify soil fertility depletion, unbalanced fertilization, and nutrient exports, and to engender policies for addressing the problems of soil fertility depletion (Sheldrick et al. 2003; Alley and Vanlauwe 2009). Nutrient budgets can be also used to assess potential environmental problems associated with the application of nutrients (Goodlass et al. 2003; Alley and Vanlauwe 2009). Nutrient budgets for individual farms reveal nutrient needs and inefficient flows and help the farmer to develop management plans for individual crops and fields. Nutrient budgets must be considered within the context of the farm's location and the farming systems. The use of budgets to identify where to improve the efficiency of nutrient use and to decrease adverse impacts has been demonstrated in northeast Scotland (Domburg et al. 2000). Experience from North America shows that nutrient budgets can mask residual soil nutrient supplies (Fixen and Johnston 2002). The importance of considering all nutrient flows in systems with limited nutrient inputs can be seen in the work by de Ridder et al. (2004).

Based on the work of Hilhorst and Muchena (2000), a typical nutrient flow analysis for a smallholder farmer consists of inflows [In1: mineral fertilizers, In2: organic inputs from outside the farm, In3: atmospheric deposition,
In4: BNF, In5: sedimentation, and In6: nutrients from the subsoil], the farm's internal flows [household livestock and fields households and livestock fields], and outflows [Out1: products leaving the farm, Out2: crop residues and animal wastes leaving the farm, Out3: leaching below the root zone, Out4: gaseous losses, Out5: erosion and runoff, and Out6: human excreta]. The balance is given as:

$$
\begin{aligned}
\text { Balance }= & {[\operatorname{In} 1+\operatorname{In} 2+\operatorname{In} 3+\operatorname{In} 4+\operatorname{In} 5+\operatorname{In} 6]-[\text { Out } 1} \\
& + \text { Out } 2+\text { Out } 3+\text { Out } 4+\text { Out } 5+\text { Out } 6]
\end{aligned}
$$

For a typical livestock farm, the components used to calculate a nutrient budget for an individual farm include seeds, fertilizer, atmospheric deposition, biological $\mathrm{N}$ fixation, purchased livestock, and feed (as inputs into the system) and animal products and crop products (as outputs from the system; Domburg et al. 2000). For arable farms, fertilizers are the major source of the input of nutrients and crop products are major sources of exports (Alley and Vanlauwe 2009).

Integrated Plant Nutrient Management helps to nourish the crop adequately while minimizing the environmental footprint. The essential element least available when all others are present in adequate quantities, the so-called Liebig's Law of the Minimum, limits plant growth (Alley and Vanlauwe 2009). The elements most widely deficient are N, P, and K, and many "complete" fertilizers contain these alone. However, several agro-ecosystems need nutrients other than N, P and K. Integrated Plant Nutrient Management utilizes all available sources to ensure that plants have adequate supplies of all the essential elements. Many fertilizers and agro-minerals contain secondary nutrients (van Straaten 2002; van Kauwenberg 2006). Acutely deficient soils can be fertilized with the required secondary and micronutrients (Bouis et al. 1999; Manson et al. 2001). Because of the diverse cropping systems, the heterogeneity of African soils, and the need for balanced plant nutrition, various initiatives have sprung up in Africa to blend fertilizers that target crops, soil types, and agroecological zones (Sanginga and Woomer 2009). For instance, Athi River Mining Company in Kenya is presently manufacturing and blending Mavuno fertilizers that contain macronutrients, secondary nutrients, and micronutrients (Poulton et al. 2006). Emerging environmental problems, linked to the mismanagement of nutrient sources of $\mathrm{N}$ and $\mathrm{P}$, such as the eutrophication of waters as observed in parts of China, call for site- and time-specific applications based on nutrient budgets. Animal manure and bio-solids should be better recycled and high rates of atmospheric $\mathrm{N}$ deposition must be taken into account in nutrient balances (Zhang et al. 2006).

Of all the plant nutrients, $\mathrm{N}$ is unique in that atmospheric reserves may be exploited as an $\mathrm{N}$ input through biological 
$\mathrm{N}$ fixation (BNF). Cultivating legumes as intercrops or in rotation is the key to exploiting BNF. Soil N must be limiting for BNF to proceed at its full potential (Giller 2001). This necessitates balanced management of $\mathrm{P}, \mathrm{K}, \mathrm{S}$, and other limiting nutrients, designated $\mathrm{P}-\mathrm{K}-\mathrm{S}+$. Identifying niches for BNF through legumes within existing farming systems is of paramount importance as the price of inorganic fertilizer increases (Sanginga and Woomer 2009).

The structural adjustment program of the 1980s and 1990s led to the disbandment of farm input subsidies in Africa. However, with increasing food insecurity, many countries are beginning to carefully bring back the issue of the farm input subsidy into their agricultural development agenda. To ensure that unintended beneficiaries do not benefit from the subsidies, the current design emphasizes the 'smart' subsidy. This depicts the critical importance of properly and unmistakably targeting the needy. With its specialized policy-led agricultural extension programs, Malawi has been the most successful with smart agricultural subsidies in Africa and has used these to stimulate farmers' investment in mineral fertilizers. This has resulted in food surpluses where in the past food security was tenuous (Denning et al. 2009).

The commonly observed shortage of food in Africa results in part from the insufficient use by farmers of fertilizers containing $\mathrm{N}$ and $\mathrm{S}$. These nutrients are required for the synthesis of amino acids by crops, which in turn relates to poor management of soil fertility. As a means of fine-tuning fertilizer recommendations and of ushering in farmers' better knowledge of soil fertility management, now is the time to introduce soil test kits to Africa. Makerere University in Kampala, Uganda, has developed soil test kits now being tested in various countries in Africa, including Kenya and Tanzania. The costs are presently high but could be reduced by the local manufacture and packaging of the refill kits of simple reagents. In the interim, the fertilizer test strips used by researchers could be commercialized through collaboration between national scientists and local fertilizer distributors. Farmers are sometimes unfamiliar with the correct usage of the available fertilizers so guidelines must be developed to ensure that they understand which fertilizers are needed in their conditions and in which amounts (Sanginga and Woomer 2009; Fig. 5).

\section{Fertilizers and plant growth}

This section reviews the role of plant nutrients and fertilizers in soil fertility maintenance and crop production. The issues examined include the supply of plant nutrients, crop yield and land use efficiency, compensation for lack of nutrients from other sources, and fertilizer repackaging. More details are given below.

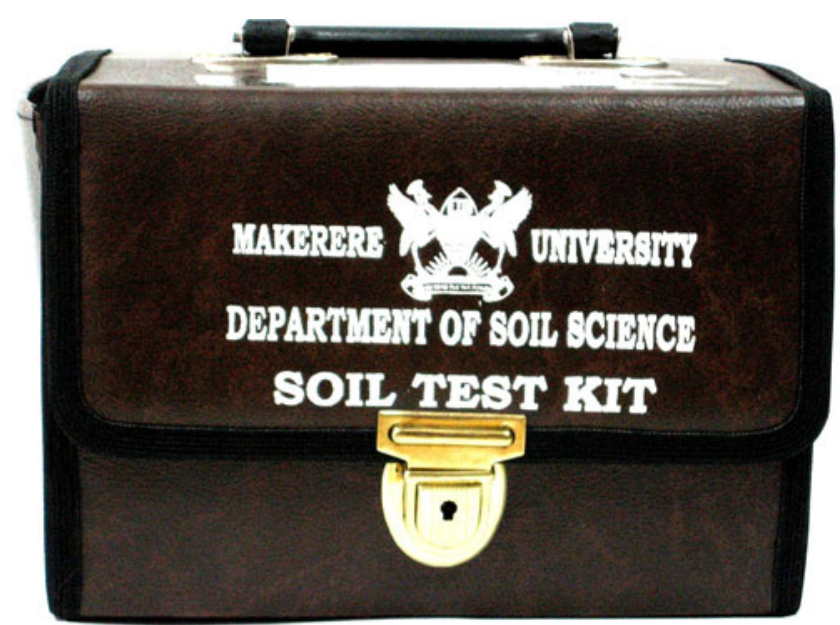

Fig. 5 Soil text kit from Makerere University, Uganda

Plant nutrients help to create sustainable agricultural systems, increase the quantity of available crop residues used as feed or as organic soil inputs, control plant diseases or reduce these to acceptable levels. Pre-plant fertilizer use is the cornerstone to improved crop productivity and the maintenance of the soil's nutrient status. Fertilizers contain concentrated nutrients and supply them to plants to replenish nutrient losses. Manufactured fertilizers could be produced from naturally occurring nutrient deposits and the industrial fixation of atmospheric N. Although the returns to fertilizer use are predictable, they are by no means certain because of the risks of drought, extreme precipitation, and fluctuating commodity prices, among others (Bationo et al. 2004a, b; Alley and Vanlauwe 2009).

Fertilizers amend soil fertility, maintain and increase the productivity of crops, and help to sustain the capacity of the soils for future crop production. Fertilizer use is particularly critical in areas where the export of nutrients from farms without replenishment has occurred for many years, resulting in increased erosion, reduced soil quality, and lower crop yields. The use of high yielding cereal varieties along with the increasing use of fertilizers containing major nutrients, even without micronutrients or organic inputs, can dramatically increase food production under many intensified systems (Okalebo et al. 2003). The application of $44 \mathrm{~kg} \mathrm{P} \mathrm{ha}{ }^{-1}$ increased cassava yield by 7 tha $^{-1}$. Not only does P fertilizer increase cassava yield, it also increases land use efficiency under an intercropping arrangement. Mason and Leihner (1988) reported an increase in land use efficiency from $30 \%$ when no P fertilizer was applied to between $41 \%$ and $50 \%$ when a cassava and cowpea intercrop received between 22 and $132 \mathrm{~kg} \mathrm{P} \mathrm{ha}^{-1}$. Up to a certain level, as the quantity of $\mathrm{K}$ applied increases, cassava plant height increases correspondingly (Nair and Aiyer 1985).

Fertilizer is an entry point for integrated soil fertility management. Manufactured fertilizers or "off-farm" nutri- 
ent sources compensate for a lack of nutrients from other sources, such as crop residues, animal manures, green manures, bio-solids, and BNF. Table 5 shows the most widely utilized manufactured fertilizers, their nutrient content, and physical state.

With the exception of rock phosphates and some superphosphates, the nutrients in the fertilizers in Table 5 are all water-soluble and plant-available. Plant availability of the $\mathrm{P}$ in rock phosphates depends on the solubility of each rock source. The superphosphate sources are not completely water-soluble, but the availability of $\mathrm{P}$ generally ranges from $97 \%$ to $100 \%$. Manufactured fertilizers have a higher concentration of nutrients than organic fertilizers. This helps to reduce transportation costs and ensure immediate availability of nutrients to plants (Quinones et al. 1997). Through split and timely application, fertilizers deliver nutrients to the crop when most needed, ensuring an efficient uptake. In addition, fertilizers can help reestablish productive cropping systems that have been degraded by nutrient depletion. However, in most circumstances, the restoration of productivity in degraded soils may be more complex and require a concerted effort combining manufactured fertilizers, organic inputs, and adapted germplasm (Alley and Vanlauwe 2009).

A large number of small-scale farmers use fertilizers at low rates. Consequently, to make fertilizers more accessible, they should be repackaged in the small quantities that farmers can afford. However, this must be devoid of corrupt practices. The development of networks of agro-input dealers able to provide farmers with accurate product information is a critical element. The loss of quality because of poor storage and adulteration during repackaging are, however, other constraints that discourage farmers from investing in fertilizer (Sanginga and Woomer 2009). This explains why fertilizer repackaging is prohibited in many countries of SSA as a means of protecting consumers from adulterated products. It is important to note that these regulations prevent local input suppliers from marketing materials in the small quantities demanded by farmers. Although the prohibition of repackaging helps to check the adulteration of fertilizers, it also reduces widespread access to fertilizers, especially where manufacturers and distributors are not interested in producing the small packages that poorer farmers would find affordable (Woomer et al. 1997; Blackie and Albright 2005; Fig. 6).

\section{Fertilizer production and importation}

This section examines the issue of fertilizer production and importation in Africa and in the face of the abundance deposits of agro-mineral resources. More details are below.

Africa is rich in phosphate rocks, the principal component of mineral fertilizers and has approximately 4.5 billion $\mathrm{t}$ of well distributed phosphate rock deposits, about $75 \%$ of the world's reserves (Sanginga and Woomer 2009; AfDB 2009). West Africa is rich in sedimentary sources of $P$ with no less than 16 major deposits in its drylands. All these

Table 5 Widely utilized fertilizers (adapted from Alley and Vanlauwe 2009)

\begin{tabular}{|c|c|c|c|c|c|c|c|}
\hline \multirow[t]{2}{*}{ Fertilizer } & \multicolumn{6}{|c|}{ Nutrient content $(\%)$} & \multirow[t]{2}{*}{ Physical state } \\
\hline & $\mathrm{N}$ & $\mathrm{P}_{2} \mathrm{O}_{5}$ & $\mathrm{~K}_{2} \mathrm{O}$ & $\mathrm{CaO}$ & $\mathrm{MgO}$ & $\mathrm{S}$ & \\
\hline Anhydrous ammonia & 82 & & & & & & Gas \\
\hline Urea & $45-46$ & & & & & & Solid \\
\hline Ammonia nitrate & $33-34.5$ & & & & & & Solid \\
\hline Calcium ammonium nitrate & $20.4-28$ & & & & & & Solid \\
\hline Urea ammonium nitrate & $28-32$ & & & & & & Liquid \\
\hline Ammonium sulfate & 21 & & & & & 24 & Solid \\
\hline Mono-ammonium phosphate & 11 & $48-55$ & & & & & Solid \\
\hline Di-ammonium phosphate & $18-21$ & $46-54$ & & & & & Solid \\
\hline Calcium nitrate & 15 & & & 34 & & & Solid \\
\hline Potassium nitrate & 13 & & 44 & 0.5 & 0.5 & 0.2 & Solid \\
\hline Rock phosphate & & $25-40^{\mathrm{a}}$ & & & & & Solid \\
\hline Single superphosphate & & $16-22$ & & & & $11-12$ & Solid \\
\hline Triple superphosphate & & $44-53$ & & & & $1-1.5$ & Solid \\
\hline Potassium chloride & & & $60-62$ & & & & Solid \\
\hline Potassium sulfate & & & $50-52$ & & & 17 & Solid \\
\hline Potassium magnesium sulfate & & & 22 & & 22 & 11 & Solid \\
\hline
\end{tabular}

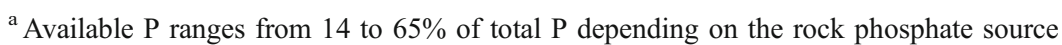




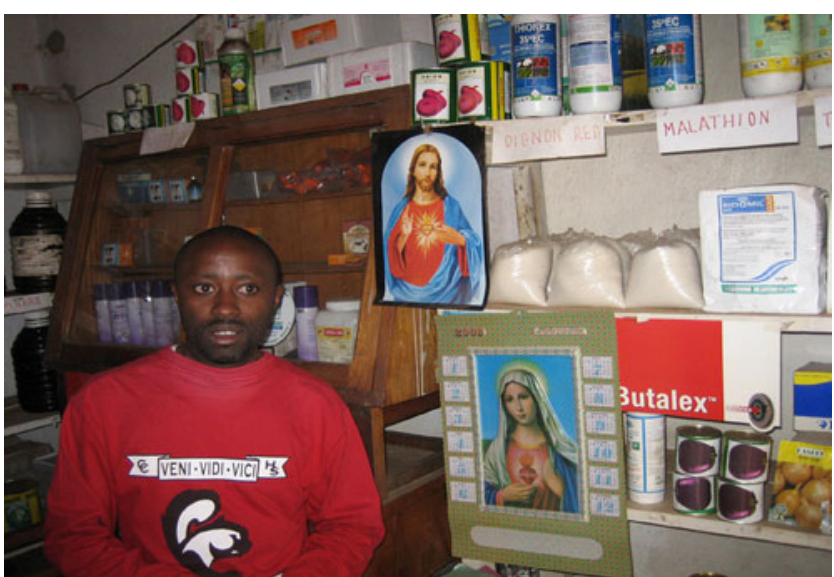

Fig. 6 Agro-input shop, Bukavu, DR Congo

deposits constitute a potential source of $\mathrm{P}$ needed to address nutrient limitations and could be utilized to replace the expensive imports (Sanchez et al. 1997; van Kauwenberg 2006). Many of the sedimentary and igneous deposits can be used in the raw or semi-processed form, especially if combined with organic resources. However, sedimentary and igneous deposits vary greatly in nutrient concentrations and solubility. Africa must, therefore, improve upon its capacities to increase the solubility of less-reactive rocks through co-granulation or partial acidulation. Plans must also be developed for the better distribution and marketing of phosphate rock in areas with widespread P deficiency. Like phosphate rock, local deposits of other agro-minerals occur throughout Africa, particularly of limestone, dolomite and gypsum that effectively correct $\mathrm{pH}$, calcium, magnesium, and sulfur imbalances in the soil. These are often mined for industrial purposes not involving fertilizer production. Clearly, benefit will be obtained from assessing the agronomic potential of current industrial by-products containing plant nutrients and then informing land managers of their comparative advantages.

Although not a major global producer of fertilizer, Africa has internationally competitive producers (AFFM 2009). Despite the large deposits of the raw materials, SSA produces only $13 \%$ of its fertilizers, importing the rest (Sanginga and Woomer 2009). Africa must expand its fertilizer industry, compete effectively to supply a larger share of domestic and international markets, and increase domestic fertilizer use (Table 6).

Zimbabwe has a relatively sophisticated fertilizer industry and produces different types of compound fertilizers. It also processes phosphate rock, limestone, and sulfide into fertilizers (van Straaten 2002) and makes N fertilizer from hydroelectric power. These facts explain why Zimbabwe is the country consuming the most fertilizer in SSA (excluding South Africa), with a consumption rate of $43 \mathrm{~kg} \mathrm{ha}^{-1}$. Zimbabwe is currently experiencing massive changes in
Table 6 Fertilizer statistics in sub-Saharan Africa: 2002 (from FAOSTAT 2004)

\begin{tabular}{lrrrr}
\hline \multirow{2}{*}{ Action } & \multicolumn{2}{l}{ Fertilizers containing } & \multirow{2}{*}{ Total fertilizers } \\
\cline { 2 - 4 } & Nitrogen & Phosphorus & Potassium & \\
& MT & & & \\
\hline Production & 110,300 & 67,050 & 0 & 177,350 \\
Importation & 709,315 & 410,740 & 288,411 & $1,408,466$ \\
Consumption & 738,943 & 409,286 & 235,369 & $1,383,598$ \\
Exportation & 43,182 & 17,825 & 35,256 & 96,263 \\
\hline
\end{tabular}

Excluding South Africa

land tenure that affect its largest commercial farms and may affect its fertilizer consumption in future. In Kenya, AthiRiver Mining Company produces two new blends of fertilizer, a basal dressing and a top-dressing marketed under the brand name Mavuno. These fertilizer blends combine imported macronutrients $\mathrm{N}$ and $\mathrm{P}$ with locally granulated minerals of gypsum and dolomitic limestone, muriate of potash, and micronutrients $\mathrm{B}, \mathrm{Zn}, \mathrm{Mn}, \mathrm{Mo}$, and $\mathrm{Cu}$. The large deposits of agro-minerals in Africa potentially offer a lower cost alternative to imported fertilizers. However, this goal cannot be achieved until mining, processing, and packaging operations are undertaken at a sufficient scale to guarantee a supply of agronomically effective materials (van Straaten 2002). Mobilizing phosphate rocks for use by African smallholders is a necessary condition for improving Africa's agricultural future. The great advantage of African phosphate rocks is their low price compared with imported P-bearing fertilizers. It is, therefore, ironic that phosphate rocks mined in Africa are exported to Europe and then re-imported to Africa as costly processed fertilizer.

Given that so little fertilizer is manufactured within most African countries, consumption matches imports, and these may be reported among other economic statistics. To achieve cost-effective transport, most countries import fertilizer with high nutrient contents, such as di-ammonium phosphate, urea, triple superphosphate, potassium chloride, and complex NPK fertilizers. Most of these fertilizers contain fewer secondary nutrients, such as $\mathrm{S}, \mathrm{Ca}$, and $\mathrm{Mg}$, and deficiencies in these micronutrients are becoming more common (Sanginga and Woomer 2009). By financing feasibility studies for establishing fertilizer plants in Mauritania, Tunisia, Algeria, the Congo, Madagascar, and Nigeria, the African Development Bank has actively promoted the intra-continental production of fertilizers. The Bank is also an equity stakeholder in a fertilizer plant in Egypt. China is establishing fertilizer plants in Nigeria and Angola. It is, however, important to note that although abundant capital investments have recently begun to bolster intra-continental fertilizer production, many of these "conventional" projects have yet to come on-line or be 
finally implemented. This helps to further explain why smallholder farmers everywhere in SSA have insufficient access to mineral fertilizers (AfDB 2009).

Fertilizer types range from single granular forms and their blends to compound or combined and complete kinds designed to provide the balanced combination of nutrients needed by specific crops. Specialized fertilizers are also available as sources of micronutrients or those that provide feeding through leaves as foliar fertilizers. Agro-minerals, such as agricultural lime, pumice, and vermiculite, are also commercially available for use as soil amendments and nutrient sources (van Straaten 2002).

\section{Factors constraining farmers' fertilizer use}

Much has been done in SSA to address declining soil fertility. However, results remain limited as widely replicable approaches are yet to be found (Murwira 2003). Several factors have been identified as major constraints to widespread fertilizer use in Africa. These factors include (1) weak access to input credit; (2) farmers' insufficient knowledge of fertilizer use; (3) inadequate policies and institutional support; (4) gender inequity; (5) weak fertilizer markets, low profitability, and inappropriate packaging sizes; and (6) high and increasing fertilizer prices. Some details are presented below.

Input credit, loans, and subsidies are critical if adoption is to be accelerated and land management technologies retained. Unfortunately, credit schemes are very rare for smallholder agriculture outside the out-grower schemes organized around export crops. Reversal of this situation calls for (1) workable smart subsidies with exit strategies to relieve the seasonal credit and cash constraints of staple crop farmers, (2) the duty-free importation of fertilizers and agro-minerals, and (3) other tax incentives to encourage farmers to make increased use of fertilizers. The fertilizer price increases have put fertilizer promotion programs and fertilizer subsidies high on the agenda of governments across Africa and their development partners (Bayite-Kasule 2009). What remains is commensurate operational action.

Without sufficient knowledge of fertilizer use, the full benefits of fertilizer use will not be achieved, leading to disincentives and reduced interest. Poor experiences with the less reactive phosphate rocks have discouraged many farmers; consequently demand for phosphate rock products was not stimulated. Active extension, farmers' training, and knowledge sharing are required to stimulate farmers' interest. Demonstration to farmers of the usefulness of phosphate rocks, emphasizing how they can be cheaper substitutes for imported fertilizers is critically important. In Tanzania, only about $2 \%$ of the agro-input dealers market Minjingu phosphate rock (Woomer et al. 1997).
Policies are critical for economic incentives which are necessary for the widespread adoption of soil fertility management technologies. Inappropriate policy regimes and a lack of bold policies affect agricultural development and food security in SSA. The widespread adoption of micro-dose technology in Niger was due to supportive policies and complementary institutional innovations linking the farmers to market. In 3 years, about 5,000 farm households in 20 pilot locations applied improved agricultural technologies, doubled their food supply, and increased farm incomes by over 50\% (Tabo et al. 2006). The number of farmers adopting the micro-dose technology has continued to grow. In Malawi, specialized policy-led agricultural extension programs, such as the Starter Pack and Targeted Input Program, resulted in a large gain. The Malawian case demonstrates how smart subsidies can stimulate farmers' investment in mineral fertilizers and result in food surpluses (Blackie and Mann 2005; Denning et al. 2009). Policies are also needed to reverse the systematic reduction in soil science capacity throughout SSA.

With respect to gender inequity, efficient and profitable farming that is equitable and charitable is the ideal. Customs that assign home and reproductive roles to women limit their commercial potential. Women's agricultural activities in Africa are often oriented towards subsistence production and the local markets (Quisumbing 1996). Gender barriers to markets create income disparities as men receive higher income from their market linkages. Women face mobility constraints that restrict their ability to sell in the distant markets offering higher prices. They also receive lower prices because they sell in smaller volumes to powerful intermediaries who set the price (OECD 2006). Both traditional value systems and their modern distortions force women to become household providers rather than income earners (Fortmann 1981). Unequal income and credit opportunities affect the abilities of women to adopt technologies. Experience from Southeastern Nigeria indicates that while the majority of Igbo women have no understanding of the use and value of fertilizer, only $25 \%$ of the men lack this knowledge (Ezumah and Di Domenico 1995). Consulting women in the actual design of a new technology can effectively make its development more demand-driven and improve the chances of adoption (Ashby et al. 2008). Women generally have poorer access to information, technology, lands, inputs, and credit (Saito and Weidemann 1990).

Too often, fertilizer markets are weak, lacking mechanisms for timely purchase and use. Sometimes, fertilizers fail to arrive where farmers can easily buy them ahead of the expected rains. Public-private partnership can be used to overcome the problems posed by weak markets and institutional constraints to widespread fertilizer adoption. Farmers' investment in inputs such as mineral fertilizers 
and agro-minerals largely depend on the availability of profitable markets for their produce (Fujisaka 1994; Buerkert et al. 2001; Patel et al. 2004). Related to this, in African farming systems, fertilizers usually arrive packaged in $50 \mathrm{~kg}$ bags. It is often illegal to repackage fertilizers into smaller sizes to reduce opportunities for adulteration and to ensure confidence about the quality. As a result, the needs of poor and vulnerable farmers, including women, are neglected. Once compliance with quality is secured, local distributors authorized to provide fertilizers in quantities from 2 to $20 \mathrm{~kg}$ are known to be providing a valuable service to poor farmers who cannot afford larger quantities (Omamo 1998; Ashby et al. 2008).

Until recently, increased fertilizer use was viewed as the central feature in reversing land degradation and achieving food security (Africa Fertilizer Summit 2006). However, the recent sharp increase in the price has called this view into question. In some quarters, greater importance is being attributed to legumes, especially within integrated soil fertility management. Since the Africa Fertilizer Summit in Abuja in 2006, prices have risen by over 130\%, largely due to the higher petroleum prices. Commodity prices have also increased but have not nearly kept pace, resulting in a very different profitability of fertilizer use compared with recommendations earlier formulated. As a result, practices that were profitable in 2004 became much less so in 2008 (Sanginga and Woomer 2009).

\section{Profitability of fertilizer use in Africa}

There is an ongoing debate as to whether or not the use of fertilizers in the farming systems of SSA is profitable. This section contributes to this debate.

Profitability is the principal incentive to adopt fertilizer and one of the major factors that determine fertilizer use patterns (Bayite-Kasule 2009). The adoption, retention, and sustainable impact of fertilizers depend on the extent to which their use is profitable. Access to profitable markets also leads to crop intensification and farmers' investments in resource management (Tiffen et al. 1994). A review of studies across SSA indicates that fertilizer use could be as profitable in Africa as it is in Asia and Latin America (Yanggen et al. 1998). In Malawi, farmers who applied fertilizer had $105 \%$ more yield and $21-42 \%$ more profit than non-adopters (Snapp et al. 2003). Sanchez et al. (1997) note that soil replenishment in Africa increased net farm incomes by $80 \%-160 \%$. Results based on several years of cowpea research in West Africa show that the minimum input of fertilizers resulted in a nearly fourfold increase in profit, and was much more profitable than the farmers' practice of a cowpea-sorghum intercrop (Tarawali et al. 2001). Annual total revenue was estimated at US \$
$300 \mathrm{ha}^{-1}$ for the best-bet option that included fertilizers and US \$ 155 for the farmers' practice. Benefit-cost ratio was 1.77 for the best-bet option compared with 1.26 for the farmers' practice. At the end of the experimental period, while the best-bet option left a net positive balance of $41 \mathrm{~kg} \mathrm{~N} \mathrm{ha}^{-1}$ and $14 \mathrm{~kg} \mathrm{P} \mathrm{ha}^{-1}$, the farmers' practice left a balance of $-28 \mathrm{~kg} \mathrm{~N} \mathrm{ha}^{-1}$ and $0.7 \mathrm{~kg} \mathrm{P} \mathrm{ha}^{-1}$. In Western Kenya, the use of fertilizers and agro-minerals in maizebased cropping systems has been found to be profitable. Compared with the control, a maize-bean intercrop, net returns increased from $57.3 \%$ to $159.6 \%$ (Woomer 2007). In the Sahel of West Africa, research results show that a one-time large application of phosphate rock has positive residual effects on crop yields during several consecutive cropping seasons, justifying its use to improve the soil's P status in the region (Mokwunye 1995; Buresh et al. 1997).

Contrary to some thinking, fertilizer use has been found to be risk-reducing in dryland farming systems. In Niger, the application of $\mathrm{P}$ has been found to cause the shorterduration millet varieties to mature earlier, reducing their exposure to drought (ICRISAT 1985-88; Shapiro and Sanders 1998). Apart from improving crop yields, fertilizer also increases the quantity of available crop residues used for livestock feed or as soil organic inputs (Bationo et al. 2004a, b). Targeting P application to legumes doubles crop biomass and increases the agronomic efficiency of fertilizer to the following cereal crop (Giller et al. 1998; Vanlauwe et al. 2003). Application of small amounts of starter $\mathrm{N}$ to legumes stimulates root growth, improved nodulation, and increased $\mathrm{N}$ contribution to a succeeding cereal crop (Giller 2001; Sanginga et al. 2001). More accurate timing and placement of top-dressed $\mathrm{N}$ during the peak demand of maize greatly improves the crop yield and agronomic efficiency (Woomer et al. 2004, 2005).

Applying small amounts of fertilizer to individual planting stations, an approach referred to as "microdosing", is an important means of improving crop yields in the African dry lands. If the fertilizer is placed in the root zone of the crops that are commonly widely spaced in the Sahel rather than being uniformly distributed, this practice results in a more efficient uptake. Yields of millet and sorghum have been observed to be between $43 \%$ and $120 \%$ higher when fertilizer micro-dosing is used than the earlier recommended broadcasting rates and the farmers' practice (Tabo et al. 2006). Micro-dosed application of mineral fertilizers is best practiced in conjunction with other technologies, such as the zai planting holes, the addition of manure or crop residues and compost. The micro-dosing technology is often supported by an inventory credit system, referred to as warrantage, which helps with the storage of agricultural produce (AFFM 2010). The zai pits are often filled with organic matter to trap and store moisture and so extend the favorable conditions for soil 
infiltration after runoff. In Burkina Faso, applying fertilizer and manure to the pits increased sorghum yields from 200 to $1,700 \mathrm{~kg} \mathrm{ha}^{-1}$. Benefits accrue to adopters during both favorable and poorer growing seasons (Reij and Thiombiano 2003). When used on the best soils with the best management practices, fertilizers are much more profitable due to gains in efficiency. Fertilizer use in Africa has to be increased significantly, preferably in the context of integrated soil fertility management aimed at inter-linkages between crops and livestock, cash and food crops, and landscapes and time. Knowing the amount of yield increase to expect per unit of fertilizer is critical for situations where availability is limited. Farmers' participatory approaches, such as experiential learning and farmer field schools, help to determine the acceptability and profitability of a technology before it is promoted at a larger scale (Alley and Vanlauwe 2009; Sanginga and Woomer 2009).

It is important to note that fertilizer use has been found to be unprofitable in certain farming systems of Africa. Fertilizer use is often unprofitable when incorrectly applied and when the soil is very poor. Under such conditions, fertilizers will lead to a yield response that is too small. Based on an econometric study on yield response to fertilizer carried out in Uganda using a farm household survey data, Nkonya et al. (2005) found that use of inorganic fertilizer appears not to be profitable for most farmers. Based on this, the study dismisses the potential of using fertilizer profitably. Mineral fertilizers should therefore only be used upon a foundation of good agronomic methods and ecological principles. It is also important to consider the training and knowledge aspects in the use of fertilizers to achieve sustainable agriculture (Fig. 7).

\section{Efficiency in the use of fertilizers}

As elsewhere, efficiency in the use of fertilizers or other nutrients is critical for the overall improvement of Africa.

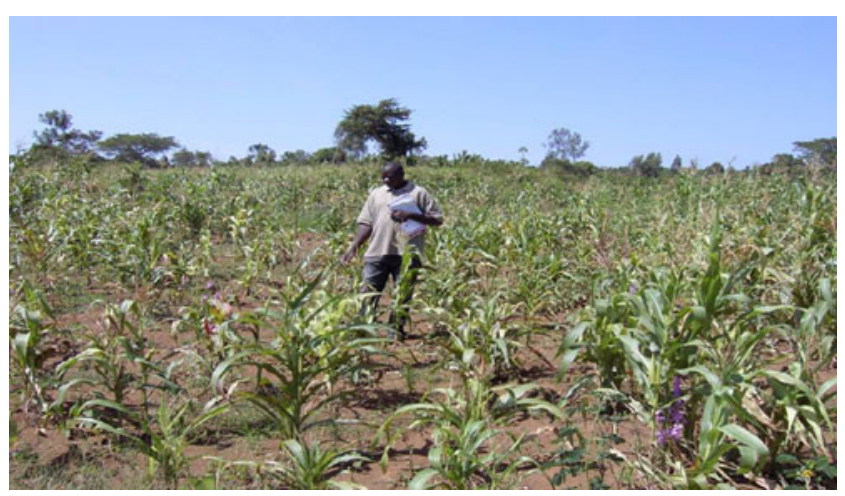

Fig. 7 A very poor soil so fertilizer use might be unprofitable
An increase in nutrient use efficiency lays the foundation for other good agricultural practices. Among others, it sustainably leads to security in food and nutrition and enhanced environmental quality while releasing resources for use in resolving other societal needs.

A high input combined with low use efficiency results in environmental footprints such as soil degradation and ground water pollution (Spiertz 2010). If farmers are not making efficient use of existing technologies, then efforts designed to improve efficiency would be more costeffective than the introduction of a new technology as a means of increasing output (Shapiro 1983). The production function specifies the technical relationships between inputs and output in a production process (Olayide and Heady 1982; Beattie and Taylor 1985; Chambers 1988; Debertin 1992). It can implicitly be expressed as:

$Y=f\left(x_{i}\right)$

where $Y$ denotes output and $x_{i}$ denote a vector of inputs, $i$ standing for the $i$ th input. Brief discussions of various factors that influence mineral fertilizer use efficiency are presented below.

Soil conditions strongly influence the efficiency with which crops use fertilizers. Crop response varies with soil type that also predicates the limiting soil nutrient. For instance, while $\mathrm{P}$ is limiting in a Nitisol, $\mathrm{N}$ is limiting in Vertisols. Generally, the crop response is reduced in degraded soils. A wider range of nutrients other than N, P, and $\mathrm{K}$ may be necessary to provide better balanced nutrient supply and engender use efficiency in such soils. Such additional nutrients may include $\mathrm{Ca}, \mathrm{Mg}$, and $\mathrm{S}$. Similarly, a critical soil content of $\mathrm{C}$ is required to obtain crop responses to the application of fertilizer. In fields with moderate $\mathrm{C}$ content, applying fertilizer accompanied by correct management strategies can considerably increase crop production (Alley and Vanlauwe 2009; Sanginga and Woomer 2009). On sandy granitic soils, N-use efficiency by maize varied from $>50 \mathrm{~kg}$ grain $\mathrm{kg}^{-1} \mathrm{~N}$ on the infields to $<5 \mathrm{~kg}$ grain $\mathrm{kg}^{-1} \mathrm{~N}$ on the outfields. This knowledge helps to guide the targeting of fertilizers to address the specific nutrient needs of each crop and to ensure use efficiency on the different soil types. When targeted to soils deficient in micronutrients, an addition of $\mathrm{Zn}$ and $\mathrm{S}$, for example, can dramatically increase fertilizer-use efficiency, yield response to available macronutrients, and overall farm profitability. For instance, supplementation by $\mathrm{S}, \mathrm{Zn}, \mathrm{B}$, and $\mathrm{K}$ increased maize yields by $40 \%$ over the standard N-P recommendation alone. Micronutrients may be included cheaply in fertilizer blends available in SSA (Wendt et al. 1994; Zingore et al. 2007b; Alley and Vanlauwe 2009). Ojiem et al. (2006) derived the concept of the socioecological niche for targeting technologies while recognizing heterogeneity among and within farms. 
Despite their high cost and the competing demands for scarce cash, farmers in Africa are learning to obtain and make judicious use of fertilizers. Organic amendments help to increase use efficiency. It is within the agricultural setting of a more effective combination of organic and mineral fertilizers that integrated soil fertility management is taking hold in Africa. Combining cereals and grain legumes through rotation, intercropping, and relays, and providing these crops with strategically applied mineral fertilizers and organic inputs are keys to integrated soil fertility management and food security. Through its combination with indigenous agrominerals and available organic resources, integrated soil fertility management offers farmers better returns to an investment in fertilizer. While producing longer-term beneficial environmental impacts, integrated soil fertility management improves the use efficiency of mineral fertilizer through its combination with organic resources (Sanginga and Woomer 2009). On less-responsive soils where other constraints are limiting crop growth, fertilizer alone in the absence of other corrective measures results in relatively low agronomic efficiencies and small improvements in yields. In these poorest soils organic resource management options must be implemented in conjunction with fertilizer addition before sufficient crop responses are possible (Carsky et al. 1998; Zingore et al. 2007a).

Improving cultural practices associated with soil fertility input use can significantly increase fertilizer use efficiency. Dry land farmers in Kenya double their maize yields by placing fertilizer $5 \mathrm{~cm}$ below and to the side of maize seeds at planting rather than applying it directly above (Bationo et al. 1997; Poulton et al. 2006). In West Africa, under low management intensity, farmers obtained $885 \mathrm{~kg} \mathrm{ha}^{-1}$ of maize compared with $2775 \mathrm{~kg} \mathrm{ha}^{-1}$ from sound agronomic soil fertility management practices. The variability of rainfall also affects the use efficiency of fertilizers and is critical in determining the risk-aversion strategies of farmers in the Sahel (Morris et al. 2007).

Agronomic efficiency is the amount of output, such as crop yield, obtained per unit of fertilizer applied. Under farmers' practices in Africa, nutrient assimilation or recoveries by crops is only $10-15 \%$ of the $\mathrm{P}$ and $10-20 \%$ of the $\mathrm{N}$ and $\mathrm{K}$ applied through fertilizer. This ineffective use of fertilizer discourages poor farmers from investing in fertilizer. Depending on its agronomic efficiency, returns to fertilizer use varies (Prudencio 1993; Manlay et al. 2002; Samake et al. 2005; Africa Fertilizer Summit 2006; Sanginga and Woomer 2009). Also important is the heterogeneity among households, their different production objectives, and resource endowments (Tittonell et al. 2005a; Giller et al. 2006). Improving agronomic efficiency entails more intensive farm management, including maintaining mineral nutrient balance, correcting soil acidity, and making effective use of limited organic resources. On responsive soils, where the fertilizer nutrients overcome the crop's nutrient limitations, substantial responses can be expected. On less-responsive soils, where other constraints are limiting, fertilizers alone result in low agronomic efficiencies and crop yields because of the absence of other corrective measures (Carsky et al. 1998; Vanlauwe et al. 2006; Zingore et al. 2007a; Fig. 8).

\section{Synergy between inorganic and organic fertilizers}

There is a common misconception that supporting the use of manufactured fertilizers means opposing the use of organic sources of nutrients. Nothing could be further from the truth. Most agronomists agree that optimal nutrient management entails starting with on-farm sources and
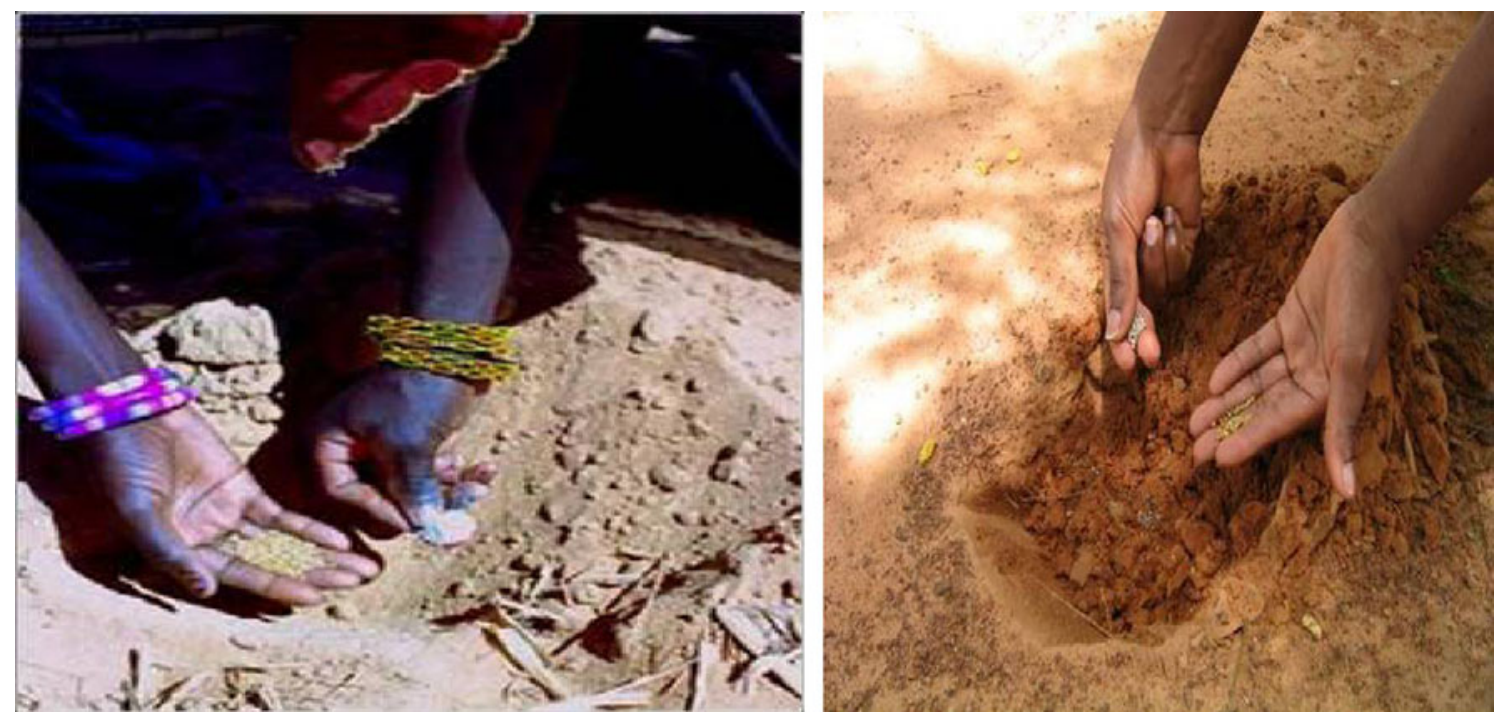

Fig. 8 Fertilizer placing under the micro-dosing, Niger 
Table 7 Paradigm shifts in soil fertility management in Africa (adapted from Alley and Vanlauwe 2009)

\begin{tabular}{|c|c|c|c|c|}
\hline Period & Paradigm & Role of fertilizer & Role of organic inputs & Experiences \\
\hline $\begin{array}{l}\text { 1960s and } \\
1970 \text { s }\end{array}$ & $\begin{array}{l}\text { External input paradigm } \\
\text { ' } 1^{\text {st }} \text { paradigm' }\end{array}$ & $\begin{array}{l}\text { Use of fertilizer alone will } \\
\text { improve and sustain yields }\end{array}$ & $\begin{array}{l}\text { Organic resources play a } \\
\text { minimal role }\end{array}$ & $\begin{array}{l}\text { Limited success due to shortfalls in } \\
\text { infrastructure, policy, farming } \\
\text { systems, etc. }\end{array}$ \\
\hline $1980 \mathrm{~s}$ & Organic input paradigm & Fertilizer plays a minimal role & $\begin{array}{l}\text { Organic resources are the main } \\
\text { source of nutrients }\end{array}$ & $\begin{array}{l}\text { Limited adoption; organic matter } \\
\text { production, processing and application } \\
\text { require a lot of land and labor }\end{array}$ \\
\hline $1990 \mathrm{~s}$ & $\begin{array}{l}\text { 'Second paradigm' - } \\
\text { spearheaded by } \\
\text { Dr Pedro Sanchez }\end{array}$ & $\begin{array}{l}\text { Fertilizer use is essential to } \\
\text { alleviate the main nutrient } \\
\text { constraints }\end{array}$ & $\begin{array}{l}\text { Organic resources are the entry } \\
\text { point (Sanchez 1994), serving } \\
\text { other functions besides } \\
\text { nutrient release }\end{array}$ & $\begin{array}{l}\text { Difficulties in obtaining organic } \\
\text { resources (e.g., improved fallows) } \\
\text { hampered adoption }\end{array}$ \\
\hline $2000 \mathrm{~s}$ & $\begin{array}{l}\text { Integrated Soil Fertility } \\
\text { Management }\end{array}$ & $\begin{array}{l}\text { Fertilizer is a major entry point } \\
\text { to increase yields and supply } \\
\text { needed organic resources }\end{array}$ & $\begin{array}{l}\text { Access to organic resources has } \\
\text { social and economic } \\
\text { dimensions }\end{array}$ & $\begin{array}{l}\text { On-going; supported by the } \\
\text { recommendation of the Africa } \\
\text { Fertilizer Summit held at Abuja in } \\
\text { 2006; several success stories so far }\end{array}$ \\
\hline
\end{tabular}

With kind permission of IFA

supplementing with manufactured fertilizers. Most agronomists also believe that nutrient interactions influence crop yields (Alley and Vanlauwe 2009). Based on agricultural research findings across SSA, a consensus has emerged that the highest and most sustainable gains in crop productivity per unit of nutrient are achieved from mixtures of fertilizers and organic inputs (FAO 1989; Pieri 1989; Giller et al. 1998; Vanlauwe et al. 2001). Through positive interactive effects on the soil's biological, chemical, and physical properties, the combination results in greater benefits. Farmers recognize the effect of the micro-dosing technology on production, especially when mulched organic inputs are also applied (Sanginga and Woomer 2009). Results from Kenya show that soil fertility technologies, combining mineral fertilizers, organic inputs, and intercropped legumes, provide positive economic returns (Woomer 2007). Combined applications of mineral fertilizers and manure, targeted at crop and soil conditions maintain soil organic matter at levels close to the original values in the Brazilian cerrado. As a result, there is the need for soil chemistry to emphasize the ameliorative influences of inorganic inputs and soil organic matter on persistent constraints to crop production (Lilienfein et al. 2003).

\section{Paradigm shifts on fertilizers}

Between 1960 and now, depending on the relative roles of mineral and organic fertilizers and the experiences gained, paradigms shifts have been noted with respect to soil fertility management in Africa (Table 7). The most recent paradigm, Integrated Soil Fertility Management, aims at sustainably improving soil fertility through increases in agronomic efficiency as fertilizer use increases over time (Sanginga and Woomer 2009).
Essentially, the earlier paradigms depict the proponents' thinking about the relative roles of mineral fertilizers and organic fertilizers in engendering increases in crop productivity and ensuring the sustainability of such increases. It was, however, observed that sustainable increases in crop productivity were not possible if the two nutrient sources are not taken into due consideration. This explains why in the current paradigm, Integrated Soil Fertility Management, although mineral fertilizers are noted to be the entry point, the essence is to underscore the fact that they are also required to speed up the production of necessary organic resources.

\section{Balanced fertilization}

Nutrient interactions influence crop yields. Alley and Vanlauwe (2009) demonstrated the maize grain yield response to applications of $\mathrm{P}$ at various levels of applied $\mathrm{N}$. Although the shapes of the yield response curves to increasing rates of $\mathrm{P}$ were similar at different $\mathrm{N}$ levels, the yields were very different, showing how $\mathrm{N}$ was limiting the

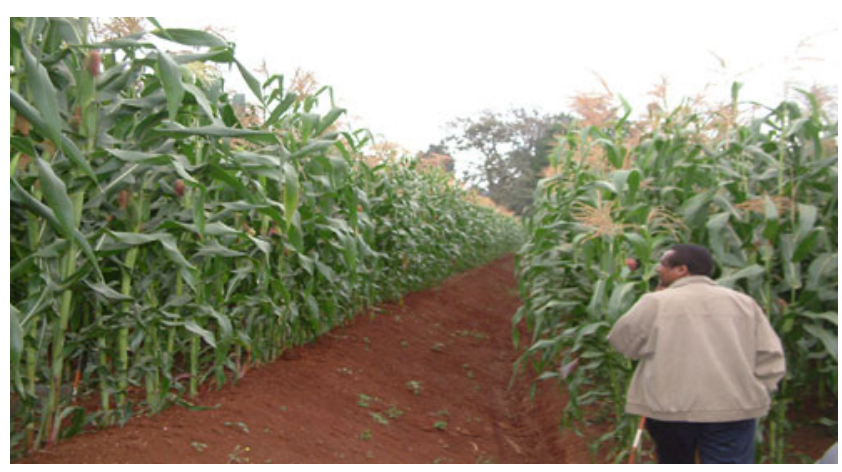

Fig. 9 Effect of balanced nutrition on maize performance, Kenya 
plant response to $\mathrm{P}$ and illustrating the need for balanced fertilization. A more balanced use of inputs requires agronomic training. Nutrient budgets are used to measure general progress towards more balanced systems. For example, $\mathrm{N}$ and $\mathrm{P}$ budgets calculated by the Organization for Economic Co-operation and Development for member countries are now used by policy makers as environmental indicators (OECD 2001). The assumption is that if nutrient inputs are greater than crop nutrient removals, the excess nutrients can be lost to ground or surface waters and the atmosphere. Although, excessive nutrient imbalances are often concentrated in small areas, the influence on downstream water quality can be dramatic. Such events have not yet happened in most of Africa. However, the African Fertilizer Financing Mechanism needs to be on the watch out for early signs as it carries out its activities in fertilizer development and promotion. Whole-farm nutrient budgets can increase farm operators' awareness of environmental concerns and encourage changes in nutrient use practices.

Usually, $\mathrm{N}$ is seen as the most critical nutrient because it is essential for plants to produce protein. However, low levels of the other essential crop nutrients can limit crop production. As a result, all plant nutrients that can limit crop growth must be determined for specific locations to enable the choice of proper fertilizers and the determination of appropriate rates of application. The use of manufactured $\mathrm{P}, \mathrm{K}, \mathrm{S}$ and micronutrient fertilizers in conjunction with $\mathrm{N}$ fertilizers in a balanced fertilization program is a key part of a total crop production system that enhances crop yields and sustains soil productivity (Alley and Vanlauwe 2009; Fig. 9).

\section{Conclusion}

The deplorable conditions of severe soil nutrient depletion and the attendant low crop yields and widespread poverty have persisted in SSA. This is also largely true of the numerous causes. These must be reversed to usher in agriculture-led economic growth in Africa. These call for targeted policies, investments, and capacity building. By so doing, Africa will successfully tap and deploy the resources it has, including the agro-mineral deposits, and use these to bring about the required reversal of soil nutrient depletion and increase in farm productivity.

Policy and institutional support are also critical to tap into and deploy the existing and tested innovations in the areas of input-output market development, nutrient budgeting, and fertilizer repackaging into sizes affordable to farmers to mention a few. All these have the potential to significantly contribute towards redressing the deplorable soil nutrient conditions in Africa.

\section{References}

AATF (African Agricultural Technology Foundation) (2006) Empowering African farmers to eradicate Striga from maize croplands. AATF, Nairobi, p 17

AfDB (African Development Bank Group) (2009) Framework for the Establishment of the Africa Fertilizer Financing Mechanism (AFFM), AfDB, Tunis, Tunisia

AFFM (Africa Fertilizer Financing Mechanism (2009) Operational strategy. AfDB, Tunis

AFFM (Africa Fertilizer Financing Mechanism) (2010) AFFM newsletter No. 1. AFFM, African Development Bank, Tunis, Tunisia

Africa Fertilizer Summit (2006) Africa fertilizer summit proceedings. IFDC, Muscle Shoals, Alabama, p 182

Alley MM, Vanlauwe B (2009) The role of fertilizers in Integrated Plant Nutrient Management, First edition, IFA, Paris, France. TSBF-CIAT, Nairobi, p 59

Ashby J, Harti M, Lambrou Y, Larson G, Lubbock A, Pehu E, Ragasa $\mathrm{C}$ (2008) Investing in women as drivers of agricultural growth. World Bank, Washington

Bananuka JA, Rubaihayo PR (1994) Banana management practices and performance in Uganda. African Crop Sci Con Proc $1: 177-182$

Bationo A (2008) Integrated soil fertility management options for agricultural intensification in the Sudano-Sahelian Zone of West Africa. Academy of Science Publisher, Nairobi, p 204

Bationo A, Mokwunye AU (1987) Soil fertility management of the millet producing sandy soils of Sahelian West Africa: the Niger experience. Paper presented at the workshop on soil and crop management systems for rainfed agriculture in the SudanoSahelian zone. International Crops Research Institute for the Semi-Arid Tropics (ICRISAT), Niamey

Bationo A, Ayuke E, Ballo D, Kon'e M (1997) Agronomic and economic evaluation of Tilemsi phosphate rock in different agroecological zones of Mali. Nutr Cycl Agroecosystems 48:179-189

Bationo A, Nandwa SM, Kimetu JM, Kinyangi JM, Bado BV, Lompo F, Kimani S, Kihanda F, Koala S (2004a) Sustainable intensification of crop-livestock systems through manure management in eastern and western Africa: lessons learned and emerging research opportunities, p. 173-198. In: Williams TO, Tarawali SA, Hiernaux P, Fernandez-Rivera S (eds) Sustainable croplivestock production for improved livelihoods and natural resource management in West Africa. International Livestock Research Institute (ILRI), Addis Ababa, Ethiopia

Bationo A, Kimetu J, Ikerra S, Kimani S, Mugendi D, Odendo M, Silver M, Swift MJ, Sanginga N (2004b) The African network for soil biology and fertility (AfNet): new challenges and opportunities. In: Bationo A (ed) Managing nutrient cycles to sustain soil fertility in sub-Saharan Africa. Academy Science Publishers, Nairobi, pp 1-23

Bationo A, Waswa B, Kihara J. and Kimetu J. eds (2006) Advances in integrated soil fertility management in sub-Saharan Africa: Challenges and opportunities. Nutrient Cycling in Agroecosystems 76: $2-3$

Bayite-Kasule S (2009) Inorganic fertilizer in Uganda-knowledge gaps, profitability, subsidy, and implications of a national policy. Uganda Strategy Support Program (USSP), Brief No. 8. International Food Policy Research Institute, Kampala

Baylies C (2002) The impact of AIDS on rural households in Africa: a shock like any other? Dev Chang 33:611-632

Beattie B, Taylor CR (1985) The economics of production. Wiley, New York

Blackie M, Albright K (2005) A lesson learning study of the farm inputs promotions project in Kenya with a special emphasis 
on public-private partnerships for input provision and possibilities for regional upscaling. Farm Inputs Promotions Project, Nairobi

Blackie M, Mann CK (2005) The origin and concept of the starter pack. In: Levy S (ed) Starter packs: a strategy to fight hunger in developing countries. Lessons from the Malawian Experience 1998-2003. CAB, Wallingford

Bouis HE, Graham RD, Welch RM (1999) The Consultative Group on International Agricultural Research Micronutrient Project: justification, history, objectives and summary of findings. Paper presented at a Workshop on Improving Human Nutrition through Agriculture: The Role of International Agricultural Research. IRRI, The Philippines

Breman H, Fofana B and Mando A (2005) The Lesson of Drente's 'Essen': soil nutrient depletion in sub-Saharan Africa and management strategies for soil replenishment. Paper presented at the International Human Dimensions Programme Open Meeting, Session on Impact of Land Use Change on Soil Resources. Bonn, Germany

Buerkert A, Bationo A, Piepho HP (2001) Efficient phosphorus application strategies for increased crop production in subSaharan West Africa. Field Crops Res 72:1-15

Buresh RJ, Sanchez PA, Calhoon F (1997) Replenishing Soil Fertility in Africa. Soil Science Society of America Special Publication No. 51, Madison, p 251

Bwamiki DP, Zake JYK, Bekunda MA, Woomer PL (1998) Use of coffee husks as an organic amendment to improve soil fertility in Ugandan banana production. In: Bergstrom L, Kirchmann $\mathrm{H}$ (eds) Carbon and nutrient dynamics in natural and agricultural tropical ecosystems. CAB, Wallingford

Carsky RJ, Iwuafor ENO (1995) Contribution of soil fertility research and maintenance to improved maize production and productivity in subSaharan Africa. Proceedings of Regional Maize Workshop. International Institute of Tropical Agriculture (IITA), Cotonou, Bénin

Carsky R, Jagtap S, Tian G, Sanginga N, Vanlauwe B (1998) Maintenance of soil organic matter and $\mathrm{N}$ supply in the moist savanna zone of West Africa. In: Lal R (ed) Soil quality and agricultural sustainability. Ann Arbor Press, Chelsea, pp 223-236

Chambers R (1988) Applied production analysis: a dual approach. Cambridge University Press, Cambridge, UK

Chianu JN, Adesina A, Sanginga P, Bationo A, Chianu JN, Sanginga N (2008) Structural change in fertilizer procurement method: assessment of impact in sub-Saharan Africa. Afr J Bus Manag 2 (3):065-071

Conway G, Toenniessen G (2003) Science for African food security. Science 299:1187-1189

Crowley E, Carter S (2000) Agrarian change and the changing relationships between toil and soil in Marigoli, Western Kenya. Hum Ecol 28:383-414

De Ridder N, Breman H, van Keulen H, Stomph TJ (2004) Revisiting a 'cure against land hunger' soil fertility management and farming systems dynamics in the West African Sahel. Agric Syst 80:109-131

De Vries J, Toenniessen G (2001) Securing the harvest: biotechnology, breeding and seed systems for African crops. CAB International, Wallingford, $\mathrm{p} 208$

Debertin DL (1992) Agricultural production economics, Reprintedth edn. Krieger, USA

Denning G, Kabambe P, Sanchez P, Malik A, Flor R, Harawa R, Nkhoma P, Zamba C, Banda C, Magombo C, Keating M, Wangila J. and Sachs J (2009) Input subsidies to improve smallholder maize productivity in Malawi toward an African green revolution. PLOS Biology 7

Derpsch R (2008) No-tillage and conservation agriculture: a progress report. In: Goddard T, Zoebisch MA, Gan YT, Ellis W, Watson A, Sombatpanit S (eds) No-till farming systems. World Association of Soil and Water Conservation, Bangkok, pp 7-39
Domburg P, Edwards AC, Sinclair AH, Chalmers NA (2000) Assessing nitrogen and phosphorus efficiency at farm and catchment scale using nutrient budgets. J Sci Food Agric 80:1946-1952

Eicher CK (1999) Institutions and the African Farmer. Economics Program Third Distinguished Economist Lecture, CIMMYT, Mexico

Ezumah NN, Di Domenico CM (1995) Enhancing the role of women in crop production: a case study of Igbo women in Nigeria. World Dev 23:1731-1744

FAO (2004) 23rd Regional Conference for Africa. FAO, Rome

FAO (2005) The state of food and agriculture. FAO Series No. 36. FAO, Rome, Italy

FAO (Food and Agriculture Organization of the United Nations) (1989) Fertilizers and food production. The FAO Fertilizer Program. 1961-1986. FAO, Rome

FAOSTAT (2004) FAO Statistics Database Rome, Italy

Fermont AM, Obiero HM, Van Asten PJA, Baguma Y, Okwuosa E (2006) Improved cassava varieties increase the risk of soil nutrient mining: an exalte análisis for Western Kenya and Uganda. In: Bationo A, Waswa B, Kihara J, Kimetu J (eds) Advances in integrated soil fertility management in sub-Saharan Africa: challenges and opportunities. Springer, Dordrecht, The Netherlands, pp 511-519

Fixen PE, Johnston AM (2002) Nutrient budgets in North America. pp. 79-85. In Plant Nutrient Use in North American Agriculture, PPI/PPIC/FAR Technical Bulletin 2002-1. Potash and Phosphate Institute, Norcross, Georgia, USA

Fortmann I (1981) The plight of invisible farmer: the effect of national agricultural policy on women. In: Dauber R, Cain M (eds) Women and technological change in developing countries. Westview, Boulder, pp 204-205

Fujisaka S (1994) Learning from six reasons why farmers do not adopt innovations intended to improve sustainability of upland agriculture. Agric Syst 46:409-425

Gachene CKK, Kimaru G (eds) (2003) Soil fertility and land productivity: guide for extension workers in the Eastern Africa region. RELMA Technical Handbook Series 30, Nairobi

Giller KE (2001) Nitrogen fixation in tropical cropping systems. CAB International, Wallingford

Giller KE, Cadisch G, Mugwira LM (1998) Potential benefits from interactions between mineral and organic nutrient sources. In: Waddington SR, Murwira HK, Kumwenda JDT, Hikwa D, Tagwira F (eds) Soil fertility research for maize-based farming systems in Malawi and Zimbabwe. Soil Fert Net and CIMMYTZimbabwe, Harare, Zimbabwe, pp 155-158

Giller KE, Rowe E, de Rider N, van Keulen H (2006) Resource use dynamics and interactions in the tropics: scaling up in space and time. Agric Syst 88:8-27

Goodlass G, Halberg N, Verschuur (2003) Input-output accounting systems in the European community-an appraisal of their usefulness in raising awareness of environmental problems. Eur J Agron 20:17-24

Hartemink AF (2003) Soil fertility decline in the tropics with case studies on plantations. International Soil Reference and Information Centre (ISRIC). Wageningen, the Netherlands and $\mathrm{CAB}$ International, Wallingford, UK

Hauser S, Nolte C and Carsky RJ (2006) What role can planted fallows play in the humid and sub-humid zone of West and Central Africa. In: Bationo A, Waswa B, Kihara J, Kimetu J (eds) Nutrient Cycling in Agroecosystems 76: 297-318

Hilhorst T, Muchena F (eds) (2000) Nutrients on the move - soil fertility dynamics in African farming systems. International Institute for Environment and Development, London

Hillocks RJ (2001) Cassava in Africa. In: Hillocks RJ, Thresh JM, Bellotti A (eds) Cassava biology, production and utilization. CAB International, Wallingford 
Howeler RH (1991) Long-term effect of cassava cultivation on soil productivity. Field Crops Res 26:1-18

Howeler RH, Cadavid LF, Calo FA (1976) The interaction of lime with minor elements and phosphorus in cassava production. Proceedings of the Fourth Symposium of International Society of Tropical Root Crops. CIAT, Cali, Colombia, pp 113-117

ICRISAT (International Crops Research Institute for the Semi-Arid Tropics) 1985-1988. Sahelian Center Annual Report. ICRISAT, Patancheru, India

IFDC (International Center for Soil Fertility and Agricultural Development) (2003) Input subsidies and agricultural development: issues and options for developing and transitional economies. Paper Series P-29. IFDC, Muscle Shoals, Alabama, p 35

Jayne TS, Goveren J, Nyoro J, Mwanaumo A, Chapoto A (2002) False promise or false premise: food market reform in Eastern and Southern Africa. World Dev 30:1967-1986

Jindal R (2006) Carbon sequestration projects in Africa: potential benefits and challenges to scaling up. Earthtrends Environmental Essay. World Resources Institute, London, UK

Jiyun Jin, Bao L, Weili Z (1999) Improving nutrient management for sustainable development of agriculture in China. pp. 157-174. In: Smaling EMA, Oenema O, Fresco LO (eds) Nutrient disequilibria in Agroecosystems, concepts and case studies. CABI, Wallingford

Jones MJ, Wild A (1975) Soils of the West African Savanna. Technical Communication No 55. Commonwealth Bureau of Soils, Harpenden, UK

Kanampiu F, Ransom J, Gressel J, Jewell D, Friesen D, Grimanelli D, Hoisington D (2002) Appropriateness of biotechnology to African agriculture: striga and maize as paradigms. Plant Cell Tissue Organ Cult 69:105-110

Kang BT (1983) Nutrient requirements and fertilization of root and tuber crops. Lecture notes, root and tuber crop production training course. International institute of Tropical Agriculture, Ibadan

Kanyanjua SM, Mureithi JG, Gachene CKK, Saha HM (2000) Soil fertility management handbook for extension staff and farmers in Kenya. Kenya Agricultural Research Institute. Technical Note Series 6, Nairobi

KARI (Kenya Agricultural Research Institute) (1994) Fertilizer use recommendations. Kenya Agricultural Research Institute. Vol 122. Fertilizer use recommendation project. KARI, Nairobi

Khan ZR, Muyekho FN, Njuguna E, Pickett JA, Wadhams LJ, Dibogo N, Ndiege A, Gemga G, Lusweti C (2005) A primer on planting and managing push-pull fields for stemborer and Striga control in maize: a step-by-step guide for farmers. International Centre of Insect Physiology and Ecology Science Press, Nairobi

Lerman Z (2001) Agriculture in transition economies: from common heritage to divergence. Agric Econ 26:95-114

Levin HM, Pollit E, Galloway R, Mcguire J (1993) Micronutrient deficiency disorders. In: Jamison DT, Mosley WH, Measham AR, Bobadilla JL (eds) Disease control priorities in developing countries. Oxford University Press, Oxford, UK, pp 421-451

Lilienfein J, Wicke W, Vilela L, Avarza MA, Do Carmo Lima S, Zech W (2003) Soil fertility under native Cerrado and pasture in the Brazilian savanna. Soil Sci Soc Am J 67:1195-1205

Lynam JK, Blackie MJ (1994) Building effective agricultural research capacity: the African challenge. In: Anderson JR (ed) Agricultural technology: policy issues for the international community. CAB International, Wallingford, UK, pp 106-134

Malavolta E, Graner EA, Coury T, Brasil Sobr MOC, Pacheco JAC (1965) Studies on the mineral nutrition of cassava. Plant Physiol 30:80-81

Manlay RJ, Kiaries M, Masse D, Chotte JL, Ciornei G, Floret C (2002) Carbon, nitrogen and phosphorus allocation in agroecosystems of a West African savanna. I. The plant component under semi-permanent cultivation. Agric Ecosyst Environ $88: 215-232$

Manning DAC (2009) Mineral sources of potassium for plant nutrition. A review. Agron. Sustain. Dev. 1-14

Manson JB, Lotfi M, Dalmiya N, Sethuraman K, Deitchler M, Geibel S, Gillenwater K, Gilman A, Mason K, Mock N (2001) The micronutrient report: current progress in the control of vitamin A, iodine, and iron deficiencies. Micronutrient Initiative. International Development Research Center, Ottawa

Mason SC, Leihner D (1988) Yield and land-use efficiency of a cassava/cowpea intercropping systems grown at different phosphorus rates. Field Crops Res 18:215-226

Millennium Ecosystem Assessment (2005) Ecosystems and human wellbeing synthesis. Island, Washington

Ministry of Agriculture National Agricultural Laboratories (MoA-NAL) (1998) Fertilizer use recommendation project (Phase I): methodology and inventory of existing information. German Agency for Technical Cooperation, National Agricultural Laboratories, Nairobi, p 115

Mokwunye AU (1995) Reactions in soils involving phosphate rocks. In: Gerner H, Mokwunye AU (eds) Use of phosphate rocks for sustainable agriculture in West Africa. International Centre for Soil Fertility and Agricultural Development, Africa

Morris M, Kelly VA, Kopicki RJ, Byerlee D (2007) Fertilizer use in African Agriculture: lessons learned and good practices guideline. World Bank, Washington, p 144

Mueller L, Schindler U, Mirschel W, Shepherd TG, Ball BC, Helming K, Rogasik J, Eulenstein F, Wiggering H (2010) Assessing the productivity function of soils. A review. Agron. Sustain. Dev. 1-11

Murwira HK (2003) Managing Africa's soils: approaches and challenges. In: Gichuru MP, Bationo A, Bekunda MA, Goma HCM, Mafongoya PL, Mugendi DN, Murwira HK, Nandwa SM, Nyathi P, Swift MJ (eds) Soil fertility management in Africa: a regional perspective. Academy Science Publishers, Nairobi, Kenya, pp 293-306

Nair PG, Aiyer RS (1985) Effect of potassium nutrition on cassava growth, yield components and yield. J Root Crops 2:23-28

Nkonya E, Pender J, Kaizzi C, Kato E, Mugarura S (2005) Policy options for increasing productivity and reducing soil nutrient depletion and poverty in Uganda. Environment and Production Technology Division Discussion paper no. 132. International Food Policy Research Institute, Washington

Odhiambo G, Woomer PL (2005) Striga emergence and seed bank dynamics under different maize management practices in Western Kenya. Afr Crop Sci Conf Proc 7:473-477

OECD (2006) Enhancing women's market access and promoting pro-poor growth: An extract from promoting pro-poor growthprivate sector development. OECD Development Assistance Committee (DAC). Organization for Economic Cooperation and Development, Paris

OECD (Organization for Economic Cooperation and Development) (2001) Environmental indicators for agriculture. Methods and results, vol. 3. Organization for Economic Co-operation and Development, Paris

Ojiem JO, de Rider N, Vanlauwe B, Giller KE (2006) Socio-ecological niche: a conceptual framework for integration of legumes in smallholder farming systems. Int J Agric Sustain 4:79-93

Okalebo JR, Gathua KW, Woomer PL (2002) Laboratory methods of soil and plant analysis, 2nd edn. SACRED-Africa Press, Nairobi, p 128

Okalebo JR, Palm CA, Lekasi JK, Nandwa SM, Otieno CO, Waigwa M, Ndungu KW (2003) Use of organic and inorganic resources to increase maize yields in some Kenyan infertile soils: a fiveyear experience. In: Bationo A (ed) Managing nutrient cycles to sustain soil fertility in sub-Saharan Africa. Academy Science Publishers, Nairobi, pp 359-372 
Okigbo BN (1990) Sustainable agricultural systems in tropical Africa. In: Edwards CA, Lal R, Madden P, Miller R, House G (eds) Sustainable agricultural systems. Soil and Water Conservation Society, Akeny, pp 323-352

Olayide SO, Heady EO (1982) Introduction to agricultural production economics, 1st edn. University of Ibadan Press, Ibadan

Omamo SW (1998) Transport costs and smallholder cropping choices: an application to Siaya district, Kenya. Am J Agric Econ 80:116-123

Omamo SW, Farrington J (2004) Policy research and African agriculture: time for a dose of reality. Natural Resource Perspective 90. Overseas Development Institute, London

Otieno H, Maina J, Omare MN, Omanya GA, Woomer PL (2005) Field testing imazapyr-resistant maize to control striga in Western Kenya. Afr Crop Sci Conf Proc 7:461-465

Patel BK, Muir-Leresche K, Coe R, Hainsworth SD (2004) The green book: a guide to effective graduate research in African agriculture, environment and rural development. The African Crop Science Society, Kampala, p 248

Pieri C (1989) Fertilité des terres de savanes; bilan de trente ans de recherché et de Développement agricole au sud du Sahara. CIRAD-IRAT, France

Place F, Barret CB, Freeman HA, Ramisch JJ, Vanlauwe B (2003) Prospects for integrated soil fertility management using organic and inorganic inputs: evidence from smallholder African agricultural systems. Food Policy 28:365-378

Poulton C, Kydd J, Dorward A (2006) Increasing fertilizer use in Africa: What have we learned? Agriculture and Rural Development Discussion Paper 25. World Bank, Washington

Prudencio CF (1993) Ring management of soils and crops in the West African semi-arid tropics: the case of the Mossi farming system in Burkina-Faso. Agric Ecosyst Environ 47:237-264

Quinones MA, Borlaug NE, Dowswell CR (1997) A fertilizer-based green revolution for A. In: Buresh RJ, Sanchez PA, Calhoun F (eds) Replenishing soil fertility in Africa. Soil Science Society of America Special Publication 51, Madison, pp 81-95

Quisumbing AR (1996) Male-female differences in agricultural productivity: methodological issues and empirical evidence. World Dev 24:1579-1595

Reij C, Thiombiano T (2003) Développement rural et environment au Burkina Faso: La rehabilitation de la capacité productive des terroirs sur la partie nord du plateau central entre 1980 et 2001. Free University of Amsterdam, Amsterdam, p 80

Roy RN, Misra RV, Lesschen JP, Smaling EMA (2003) Assessment of soil nutrient balance, approaches and methodologies. FAO fertilizer and plant nutrition bulletin 14. FAO, Rome

Saito KA, Weidemann CJ (1990) Agricultural extension for women farmers in Africa. Policy Research Working Paper Series No 393. The World Bank, Washington

Samake O, Smaling EMA, Kropff MJ, Stomph TJ, Kodio A (2005) Effects of cultivation practices on spatial variation of soil fertility and millet yields in the Sahel of Mali. Agric Ecosyst Environ 109:335-345

Sanchez PA (1994) Tropical soil fertility research: towards the second paradigm. State-of-the-Art Lecture, XV International Soil Science Congress, 10-16 July 1994, Acapulco, Mexico

Sanchez PA, Shepherd JD, Soule MJ, Place FM, Buresh RJ, Izac AMN, Mukwonye AU, Keswiga FR, Ndiritu CG, Woomer PL (1997) Soil fertility replenishment in Africa: an investment in natural resource capital. In: Buresh RJ, Sanchez PA, Calhoun F (eds) Replenishing soil fertility in Africa. SSSA Special Publication No. 51. Soil Science Society of America, Madison, pp $1-46$

Sanginga N, Woomer PL (2009) Integrated soil fertility management in Africa: principles, practices and developmental process. Tropical Soil Biology and Fertility Institute of the International Centre for Tropical Agriculture, Nairobi, p 263
Sanginga N, Okogun JA, Vanlauwe B, Diels J, Dashiell K (2001) Contribution of nitrogen fixation to the maintenance of soil fertility with emphasis on promiscuous soybean maize-based cropping systems in the moist savanna of West Africa. In: Tian G, Ishida F, Keatinge JDH (eds) Sustaining soil fertility in West Africa. American Society of Agron, Madison, pp 157-178

Sayang S, Ajayi A, Sy AA (2002) Proceedings of the second biennial regional rice review. The Africa Rice Center (WARDA), Bouaké, Côte d'Ivoire

Seward P, Okello D (1999) Rural roads and natural resource management in the semi-arid lands of Kenya, Mini-pac method. SCODP Special Report No 1. Sustainable Community Oriented Development Programme, Siaya, Kenya

Shapiro KH (1983) Efficiency differentials in peasant agriculture and their implications for development policies. J Dev Stud 19:179-190

Shapiro BI, Sanders JH (1998) Fertilizer use in semi-arid West Africa: profitability and supporting policy. Agric Syst 56:467-482

Sheldrick WF, Syers JK, Lingard J (2003) Soil nutrient audits for China to estimate nutrient balances and out/input relationships. Agric Ecosyst Environ 94:341-354

Shepherd KD, Soule MJ (1998) Soil fertility management in West Kenya: dynamic simulation of productivity, profitability and sustainability at different resource endowment levels. Agric Ecosyst Environ 71:131-145

Sifri Z, Darnton-Hill I, Baker SK, Bendech MA, Baker SK, Aguayo VM, Bendech MA (2003) A concise overview of micronutrient deficiencies in Africa and future directions. Afr J Food Agric Nutr Dev 2:78-85

Sillanpa M (1990) Micronutrient assessment at the country level: an international study. FAO Soils Bulletin 63. FAO, Rome

Slingerland MA, Traore K, Kayode PA, Mitchikpe E (2006) Fighting Fe deficiency malnutrition in West Africa: an interdisciplinary program on a food chain approach. NJAS 53(3-4):253-279

Smaling EMA, Nandwa SM, Presteele H, Roetter RA, Muchena FN (1992) Yield response of maize to fertilizer and manure under different agro-ecological conditions in Kenya. Agric Ecosyst Environ 41:241-252

Smaling EMA, Nandwa SM, Janssen BH (1997) Soil fertility is at stake! In: Buresh RJ, Sanchez PA, Calhoun F (eds) Replenishing soil fertility in Africa. SSSA Special Publication No. 51. Soil Science Society of America, Madison, pp 47-61

Smaling EMA, Toure M, de Ridder N, Sanginga N, Breman H (2006) Fertilizer use and the environment in Africa: friends or foes? Background Paper prepared for the African Fertilizer Summit, Abuja, Nigeria

Snapp SS, Nyiraneza J, O'Neil K (2003) Organic inputs and a cover crop short rotation for improved potato productivity and quality. In: Michigan Potato Research Report. Vol. 34. Michigan State University Agricultural Experimental Station in cooperation with the Michigan Potato Industry Commission, East Lansing, pp $139-144$

Spiertz JHJ (2010) Nitrogen, sustainable agriculture and food security. A review. Agron Sustain Dev 30:43-55

Stoorvogel JJ, Smaling EMA, Janssen BH (1993) Calculating soil nutrient balances in Africa at different scales. Supra-national scale. Fertil Res 35:227-335

Swift MJ, Shepherd KD (eds) (2007) Saving Africa's soils: science and technology for improved soil management in Africa. World Agroforestry Centre, Nairobi, Kenya

Tabo R, Bationo A, Gerald B, Ndjeunga J, Marchal D, Amadou B, Annou MG, Sogodogo D, Taonda JBS, Hassane O, Diallo MK, Kaola S (2006) Improving cereal productivity and farmers' income using a strategic application of fertilizers in West Africa. In: Bationo A, Waswa BS, Kihara J, Kimetu J (eds) Advances in integrated soil fertility management in sub- 
Saharan Africa: challenges and opportunities. Springer, the Netherlands, pp 201-208

Tarawali SA, Larbi A, Fernandez-Rivera S, Bationo A (2001) The role of livestock in the maintenance and improvement of soil fertility. In: Tian G, Ishida F, Keatinge JDH (eds) Sustaining soil fertility in West Africa. Soil Science Society of America Special Publication No. 58. Soil Science Society of America and American Society of Agronomy, Madison, pp 281-304

Tiffen MM, Mortimore M, Gichuki (1994) More people, less erosion: environmental recovery in Kenya. Wiley, New York

Tittonell P, Vanlauwe B, Leffelaar PA, Rowe E, Giller KE (2005a) Exploring diversity in soil fertility management of smallholder farms in Western Kenya. I. Heterogeneity at region and farm scale. Agric Ecosyst Environ 110:149-165

Tittonell P, Vanlauwe B, Leffelaar PA, Shepherd KD, Giller KE (2005b) Exploring diversity in soil fertility management of smallholder farms in Western Kenya. II. Within farm variability in resource allocation, nutrient flows and soil fertility status. Agric Ecosyst Environ 110:166-184

Tripp R (2006) Is low external input technology contributing to sustainable agricultural development? Natural Resource Perspective No. 102. Overseas Development Institute, London

Uphoff N, Ball A, Fernandez E, Herren H, Husson O, Laing M, Palm C, Pretty J, Sanchez P (eds) (2006) Biological approaches to sustainable soil systems. CRC, Boca Raton, p 784

van de Steeg JA, Herrero M, Kinyangi J, Thornton PK, Rao KPC, Stern R, Cooper P (2009) The infl uence of climate variability and climate change on the agricultural sector in East and Central Africa-Sensitizing the ASARECA strategic plan to climate change. Research report 22. ILRI (International Livestock Research Institute), Nairobi, Kenya, ICRISAT (International Crop Research Institute for the Semi-Arid Tropics), Nairobi, Kenya, and ASARECA (Association for Strengthening Agricultural Research in Eastern and Central Africa), Entebbe, Uganda

Van der Pol F (1992) Soil mining: an unseen contribution to farm income in Southern Mali. Bulletin 325. Institut Royal des Tropiques, Amsterdam

Van Kauwenberg SJ (2006) Fertilizer raw material resources of Africa. Reference Manual 16. IFDC, Muscle Shoals, Alabama

Van Rensburg HJ, Strijdom BW, Kriel MM (1976) Necessity for seed inoculation of soybeans in South Africa. Phytophylactica 8:91-96

Van Reuler H, Janssen BH (1996) Optimum P management over extended cropping periods in the shifting cultivation system of south-west Côte d'Ivoire. Neth J Agric Sci 44:263-277

Van Straaten P (2002) Rocks for crops: agrominerals of sub-Saharan Africa. International Centre for Research in Agroforestry (ICRAF), Nairobi, p 338

Vanlauwe B, Giller KE (2006) Popular myths around soil fertility management in sub-Saharan Africa. Agric Ecosyst Environ 116:34-46

Vanlauwe B, Wendt J, Diels J (2001) Combined application of organic matter and fertilizer. In Tian G, Ishida F, Keatinge JDH (eds) Sustaining soil fertility in West-Africa. SSSA Special Publication Number 58, Madison, WI, USA, pp 247-280

Vanlauwe B, Bationo A, Carsky RJ, Diels J, Sanginga N, Schulz S (2003) Enhancing the contribution of legumes and biological nitrogen fixation in cropping systems: experiences from West Africa. Grain legumes and green manures of soil fertility in Southern Africa: taking stock of progress. Proceedings of a SoilFertNet meeting, 8 11 October 2002, Vumba, Zimbabwe, pp 3-13

Vanlauwe B, Tittonell P, Mukalama J (2006) Within-farm soil fertility gradients affect response of maize to fertilizer application in western Kenya. Nut Cycl Agroecosyst 76:171-182

Wendt JW, Jones RB, Itimu OA (1994) An integrated approach to soil fertility improvement in Malawi, including agroforestry. In: Craswell ET, Simpson J (eds). Soil fertility and climatic constraints in dryland agriculture. Australian Council for International Agricultural Research Proceedings No. 54. Canberra, Australia. pp 74-79

Wiggens S, Slater R (2005) Responding to HIV/AIDS in agriculture and related activities. Natural Resource Perspective No. 58. Overseas Development Institute, London

Woomer PL (2007) Costs and returns to soil fertility management options in Western Kenya. In: Bationo A (ed) Advances in integrated soil fertility research in sub-Saharan Africa: challenges and opportunities. Springer, Dordrecht, The Netherlands, pp 877-885

Woomer PL, Muchena FN (1996) Recognizing and overcoming soil constraints to crop production in tropical Africa. Afr J Crop Sci 14:503-518

Woomer PL, Martin A, Albrrecht A, Resck DVS, Sharpenseel HW (1994) The importance and management of soil organic matter in the tropics. In: Woomer PL, Swift MJ (eds) The biological management of tropical soil fertility. Wiley, Chichester, pp 47-80

Woomer PL, Karanja NK, Mekki EI, Mwakalombe B, Tembo H, Nyika M, Nkwiine C, Ndakidemi P, Msumali G (1997) Indigenous populations of rhizobia, legume response to inoculations and farmer awareness of inoculants in East and Southern Africa. Afr Crop Sci Conf Proc 3:297-308

Woomer PL, Bekunda M, Nkalubo S (1999) Estimation of banana yield based on bunch phenology. Afr Crop Sci J 7:341-347

Woomer PL, Lan'gat M, Tungani JO (2004) Innovative maize-legume intercropping results in above- and below-ground competitive advantages for understory legumes. West Afr J Appl Ecol 6:85-94

Woomer PL, Tungani J, Odhiambo G, Mwaura FM (2005) Striga management options in western Kenya. Afr Crop Sci Conf Proc 7:479-484

Woomer PL, Bokanga MA, Odhiambo GD (2008) Striga management and the African Farmer. Outlook Agric 37:245-310

Yanggen D, Kelly V, Reardon T, Naseem A (1998) Incentives for fertilizer use in sub-Saharan Africa: a review of empirical evidence on fertilizer yield response and profitability. International Development Working Paper No. 70. Michigan State University, East Lansing

Zhang F, Wang J, Zhang W (2006) Sustainable use of plant nutrients in China. Proceedings of the IFA Agriculture Conference "Optimizing Resource Use Efficiency for Sustainable Intensification of Agriculture", 27 February - 2 March 2006, Kunming, China. International Fertilizer Industry Association, Paris

Zingore S, Murwira HK, Delve RJ, Giller KE (2007a) Influence of nutrient management strategies on variability of soil fertility, crop yields and nutrient balances on smallholder farms in Zimbabwe. Agric Ecosyst Environ 119:112-126

Zingore S, Murwira HK, Delve RJ, Giller KE (2007b) Soil type, historical management and current resource allocation: three dimensions regulating variability of maize yields and nutrient use efficiencies on African smallholder farms. Field Crops Res 101:296-305 